\title{
Report on the External Quality Assessment Scheme of Hepatitis Viral Markers in Korea, (2016-2017)
}

Eun-Jung Cho ${ }^{1}$, Ae Ran Choi ${ }^{2}$, Ji Hyeong $\mathrm{Ryu}^{2,3}$, So Jeong Yun ${ }^{2,3}$, Woochang Lee ${ }^{4}$, Sail Chun ${ }^{4}$, Won-Ki Min ${ }^{4}$, and Eun-Jee $\mathrm{Oh}^{2}$

${ }^{1}$ Department of Laboratory

Medicine, Uijeongbu St.

Mary's Hospital, College

of Medicine, The Catholic

University of Korea,

Uijeongbu; ${ }^{2}$ Department of

Laboratory Medicine, Seoul

St. Mary's Hospital, College

of Medicine, The Catholic

University of Korea;

${ }^{3}$ Department of Molecular

\& Cell Biology, Graduate

School, The Catholic

University of Korea;

${ }^{4}$ Department of Laboratory

Medicine, Asan Medical

Center, University of Ulsan

College of Medicine, Seoul,

Korea
As part of the immunoserology program of the Korean Association of External Quality Assessment Service, we organized two trials on the external quality assessment of hepatitis viral markers in 2016 and 2017. The hepatitis viral antigens and antibodies program consisted of 10 test items. We delivered two and three types of pooled sera specimens to 965 and 965 institutions for the first and second trials of external proficiency testing in 2016, respectively. The number of participating laboratories was 915 (94.8\%) and 913 (95.0\%) in the first and second trials in 2016, respectively. We also delivered three kinds of pooled sera specimens to 936 and 1,015 institutions for the first and second trials of external proficiency testing in 2017, respectively. The number of participating laboratories was 920 (98.3\%) and $996(98.1 \%)$ in the first and second trials in 2017, respectively. The most commonly tested items were hepatitis B surface antigen, followed by the antibodies to hepatitis B surface antigen, anti-hepatitis $C$ virus, hepatitis $B$ envelope antigen, antibodies to hepatitis $\mathrm{B}$ envelope antigen, anti-hepatitis $\mathrm{A}$ virus and antibodies to hepatitis B core antigen. The most frequently used methods for detecting viral markers were the chemiluminescence immunoassay and the electrochemiluminescence immunoassay, but they yielded a few-false positive results due to the matrix effect. The immunochromatographic assay yielded falsenegative results for anti-hepatitis A virus due to low sensitivity. Continuous improvement in the quality of viral hepatitis testing through participation in the survey seems necessary.

(J Lab Med Qual Assur 2018;40:51-69)

Key Words: External quality assessment, Hepatitis A, Hepatitis B, Hepatitis C, Immunoassay, Laboratory proficiency testing, Pooled serum
Corresponding author:

Eun-Jee Oh

Department of Laboratory

Medicine, Seoul St. Mary's

Hospital, College of Medicine,

The Catholic University of Korea,

222 Banpo-daero, Seocho-gu,

Seoul 06591, Korea

Tel: +82-2-2258-1641

Fax: +82-2-2258-1719

E-mail: ejoh@catholic.ac.kr 


\section{Journal of LABORATORY MEDICINE and QUALITY ASSURANCE}

\section{Eun-Jung Cho et al • Report on EQA for Hepatitis Viral Markers}

\section{서론}

대한임상검사정도관리협회 면역혈청분과위원회는 1982년 B형간염표면항원(hepatitis B surface antigen, $\mathrm{HBsAg}$ ) 검 사와 매독혈청검사(serologic test for syphilis)에 대한 신빙도 조사를 시작으로[1], 1983년부터 항-스트렙토라이신 O (antistreptolysin O)와 위달(Widal) [2], 1986년부터 C-반응단백 (C-reactive protein), 류마토이드인자(rheumatoid factor), B형간염표면항체(antibody to hepatitis B surface antigen, anti-HBs) [3], 1992년부터 에이즈항체(anti-human immunodeficiency virus), 1993년부터 C형간염항체(antihepatitis C virus, anti-HCV) [4], 2004년부터 B형간염중심 항체(antibody to hepatitis B core antigen, anti-HBc) 검사 를 신빙도조사에 추가하였다[5]. 2016년부터는 B형간염외피 항원(hepatitis B envelope antigen, $\mathrm{HBeAg}$ ), B형간염외피 항체(antibody to hepatitis envelope antigen, anti-HBe) 및 A형간염항체(anti-hepatitis A virus, anti-HAV) 검사가 추 가되었으며, 차세대 신빙도조사사업 시행에 따라 분과위원회 가 없어지고 기존의 바이러스 항원/항체 및 매독항체검사 신 빙도조사사업은 간염바이러스 항원항체검사와 바이러스 항 원항체검사 신빙도조사사업으로 분리하여 시행되고 있다. 간 염바이러스 항원항체검사 신빙도조사사업은 $\mathrm{HBsAg}$, anti$\mathrm{HBs}$, anti-HBc total, anti-HBc immunoglobulin M (IgM), $\mathrm{HBeAg}$, anti-HBe, anti-HCV, anti-HAV total, anti-HAV immunoglobulin G (IgG), anti-HAV IgM 등 총 10종목에 대 하여 연 2회 실시되었으며, 저자들은 2016년과 2017년에 실시 한 간염바이러스 항원항체검사의 신빙도조사결과를 분석하여 보고하고자 한다.

\section{재료 및 방법}

\section{1. 신빙도조사 검체 및 대상기관}

연 2회에 걸쳐 간염바이러스 항원항체검사에 대한 신빙도조 사를 실시하였다. 2016년도 1회차 신빙도조사 검체는 총 2개 (IL-16-01, IL-16-02)의 검체를 965개 기관에, 2 회차에는 총 3 개의 검체(IL-16-03, IL-16-04, IL-16-05)를 962개 기관에 각각 2016년 6월과 10월에 발송하였다. 2017년도 1회차 신빙 도조사 검체는 총 4개( $\mathrm{IL}-17-01, \mathrm{IL}-17-02$, IL-17-03, IL-1704)의 검체를 936 개 기관에, 2 회차에도 1 회차와 마찬가지로 총 4개(IL-17-05, IL-17-06, IL-17-07, IL-17-08)의 검체를 1,015 개 기관에 각각 2017 년 5 월과 10 월에 발송하였다.

\section{2. 신빙도조사 대상종목}

신빙도조사 대상종목은 $\mathrm{HbsAg}$, anti-HBs, anti-HBc total, anti-HBc IgM, HbeAg, anti-Hbe, anti-HCV, antiHAV total, anti-HAV IgG, anti-HAV IgM 총 10종목이었고, 2016년과 2017년도 1회차와 2회차 모두 동일한 종목을 대상 으로 하였다.

\section{3. 신빙도조사 검체 제조방법}

2016년도 신빙도조사를 위한 검체는 서울아산병원에서 제 조하였으며, 2017년도 검체는 서울성모병원에서 제조하였다. ‘한마음혈액원'으로부터 혈장을 분양받아 각 종목의 양성과 음 성 신빙도조사 검체를 자가제조하였다. 제조방법은 신선동결 혈장(fresh frozen plasma), thrombin, $\mathrm{CaCl} 2$ 를 잘 혼합한 후 $37^{\circ} \mathrm{C}$ 항온수조(water bath)와 냉동에서 반응시키고, 3,000 $\mathrm{rpm}, 4^{\circ} \mathrm{C}, 20$ 분간 원심분리과정을 통하여 혼합혈청(pooled serum)을 제조하였다. $0.22 \mu \mathrm{m}$ 필터에서 1 회 여과시킨 다음 각 종목에 따라 적절한 역가가 되도록 양성 혈청을 혼합하여 교반기에서 1 시간 정도 섞는 과정을 거쳤다. 1 회차 및 2 회차에 제조된 2016년도 5개 검체와 2017년도 8개 검체의 대상 검사 항목과 예상결과는 Table 1 에 정리하였으며, 최종 균질성 확 보를 위하여 $4^{\circ} \mathrm{C}$, 교반기에서 18 시간 동안 혼합과정을 거친 후 3 개 이상의 제조회사 장비로 검체의 정성결과 값이 일치하는 지 확인하였다(Table 2).

\section{4. 결과분석 및 통계}

물질을 수령한 참여기관에서는 검사 시행 후 사전에 공지 된 일정에 따라 지정된 회신 마감일 이내에 검사결과를 대한임 상검사정도관리협회 신빙도조사사업 홈페이지(http://eqas keqas.org)에 입력하도록 하였다. 각 검사항목별로 참여기관 에서 사용하고 있는 장비에 따라 분류하여 결과를 분석하였다. 통계분석에는 IBM SPSS Statistics for Windows ver. 24.0 (IBM Corp., Armonk, NY, USA)과 MedCalc Statistical Software ver. 16.8.4 (MedCalc Software bvba, Ostend, Belgium)를 사용하였다. 각 기관별 분석결과 및 기기별 통계 결과를 협회 홈페이지에서 직접 조회하고 출력할 수 있도록 하 였다.

\section{결과}

\section{1. 참여기관 및 회신율}

2016년도 최소 1종목 이상 신빙도조사에 참여한 기관들을 기준으로 1 회차는 965 기관 중 915 기관이, 2 회차는 962 기관 중 


\section{Journal of LABORATORY MEDICINE and QUALITY ASSURANCE}

Eun-Jung Cho et al • Report on EQA for Hepatitis Viral Markers

Table 1. Intended results of external quality control specimens for hepatitis viral antigen and antibody assessment

\begin{tabular}{|c|c|c|c|c|c|c|c|c|c|c|}
\hline Analyte & HBsAg & Anti-HBs & $\begin{array}{c}\text { Anti-HBc } \\
\text { total }\end{array}$ & $\begin{array}{c}\text { Anti-HBc } \\
\text { IgM }\end{array}$ & $\mathrm{HBeAg}$ & Anti-HBe & $\begin{array}{l}\text { Anti- } \\
\mathrm{HCV}\end{array}$ & $\begin{array}{c}\text { Anti-HAV } \\
\text { total }\end{array}$ & $\begin{array}{c}\text { Anti-HAV } \\
\text { IgG }\end{array}$ & $\begin{array}{c}\text { Anti-HAV } \\
\text { IgM }\end{array}$ \\
\hline \multicolumn{11}{|c|}{ 2016-1st trial } \\
\hline IL-16-01 & - & + & + & - & - & + & + & + & + & - \\
\hline IL-16-02 & + & - & + & - & - & + & - & + & + & - \\
\hline \multicolumn{11}{|c|}{ 2016-2nd trial } \\
\hline IL-16-03 & - & - & - & - & - & - & + & - & - & - \\
\hline IL-16-04 & + & - & + & - & + & - & - & + & + & - \\
\hline IL-16-05 & - & + & + & - & - & - & - & + & + & - \\
\hline \multicolumn{11}{|c|}{ 2017-1st trial } \\
\hline IL-17-01 & - & + & - & - & - & - & & & & \\
\hline IL-17-02 & + & - & + & - & - & + & & & & \\
\hline IL-17-03 & & & & & & & - & + & + & + \\
\hline IL-17-04 & & & & & & & + & + & + & - \\
\hline \multicolumn{11}{|c|}{ 2017-2nd trial } \\
\hline IL-17-05 & + & - & + & - & + & - & & & & \\
\hline IL-17-06 & - & + & - & - & - & - & & & & \\
\hline IL-17-07 & & & & & & & - & - & - & - \\
\hline IL-17-08 & & & & & & & + & + & + & - \\
\hline
\end{tabular}

Abbreviations: $\mathrm{HBsAg}$, hepatitis B surface antigen; anti-HBs, antibody to $\mathrm{HBsAg}$; anti-HBc, antibody to hepatitis B core antigen; $\mathrm{HBeAg}$, hepatitis B envelope antigen; anti-HBe, antibody to $\mathrm{HBeAg}$; anti-HCV, antibody to hepatitis $\mathrm{C}$ virus; anti-HAV, antibody to hepatitis A virus.

Table 2. Methods used for mock survey of external quality control specimens for hepatitis viral antigen and antibody assessment

\begin{tabular}{lll}
\hline \multicolumn{1}{c}{ Method } & \multicolumn{1}{c}{ Instruments } & \multicolumn{1}{c}{ Reagents } \\
\hline Electrochemiluminescence immunoassay & Cobas e600, e800 series/E170, Roche & Reagent for E170 \\
Chemiluminescence immunoassay & Architect, Abbott & Reagent for Architect \\
& Centaur XP/XPT, Siemens & Reagent for Centaur XP \\
& UniCel DxI 800, Beckman Coulter & Reagent for UniCel DxI 800 \\
Fluorescence enzyme immunoassay & Vitros 3600, Ortho-Clinical Diagnostics & Reagent for Vitros 3600 \\
\hline
\end{tabular}

The instruments used were from the following companies: Cobas e600 series/E170 (Roche Diagnostics GmbH, Mannheim, Germany), Architect (Abbott Diagnostics, Abbott Park, IL, USA), Centaur XP/XPT (Siemens Healthcare Diagnostics, Tarrytown, NY, USA), UniCel DxI 800 (Beckman Coulter Inc., Brea, CA, USA), Vitros 3600 (Ortho Clinical Diagnostics, Raritan, NJ, USA), and VIDAS (BioMérieux, MarcyL'Etoile, France).

913기관이 회신하여 회신율은 각각 $94.8 \%, 95.0 \%$ 였다. 2 차 신빙도조사를 기준으로 각 기관 유형별 참여현황 및 세부 종 목별 참여현황은 Table 3에 정리하였다. 2017년도 최소 1종목 이상 신빙도조사에 참여한 기관들을 기준으로 1회차는 936기 관 중 920 기관이, 2 회차는 1,015 기관 중 996 기관이 회신하여 회신율은 각각 $98.3 \%, 98.1 \%$ 였다. 2 차 신빙도조사를 기준으 로 각 기관 유형별 참여현황 및 세부 종목별 참여현황은 Table 3에 제시하였다. 2013년부터 2015년까지의 바이러스 항원/항
체 및 매독항체검사[6-8] 및 2016년과 2017년의 간염바이러 스 항원항체검사 2 차 신빙도조사의 참여기관 및 회신율을 정 리하였다(Fig. 1).

\section{2. 검사방법 및 검사장비}

신빙도조사에 참여한 기관들의 검사항목별 검사방법 및 사용장비는 협회 홈페이지에 각 기관이 기재한 코드를 바 탕으로 분석하였다. 2 차 신빙도조사를 기준으로 각 검사실 


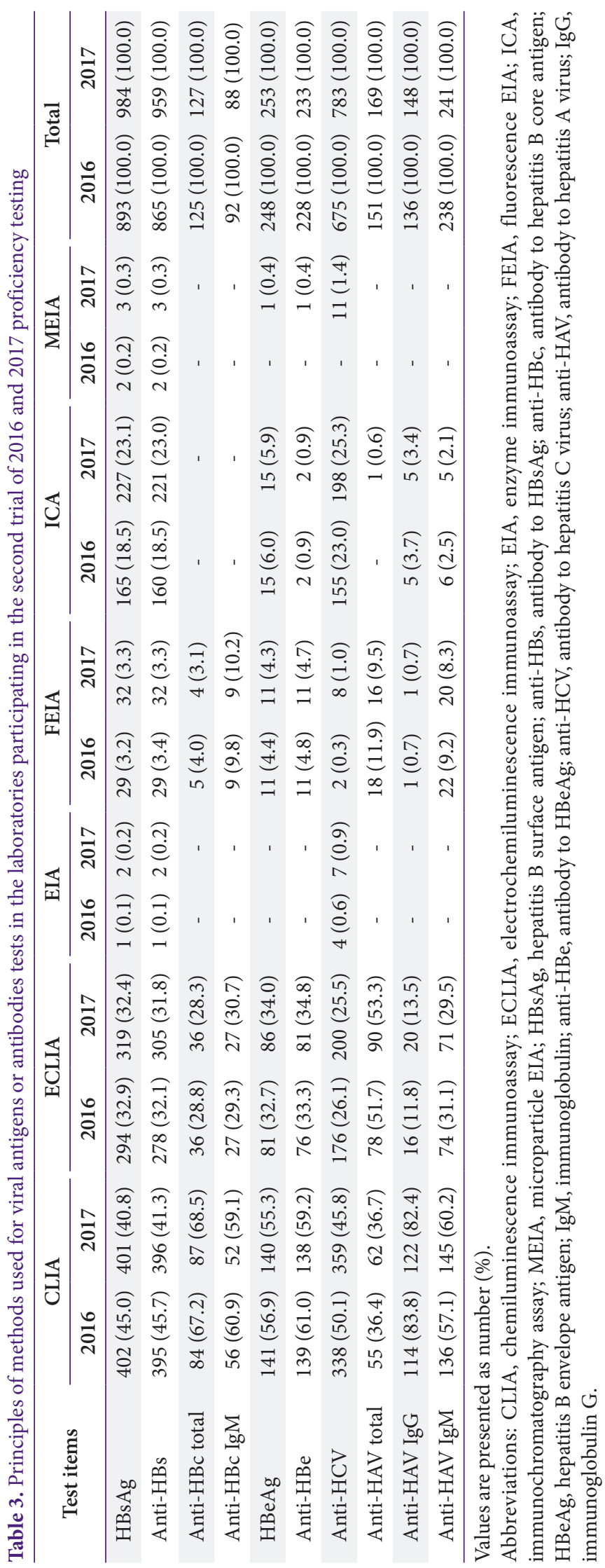

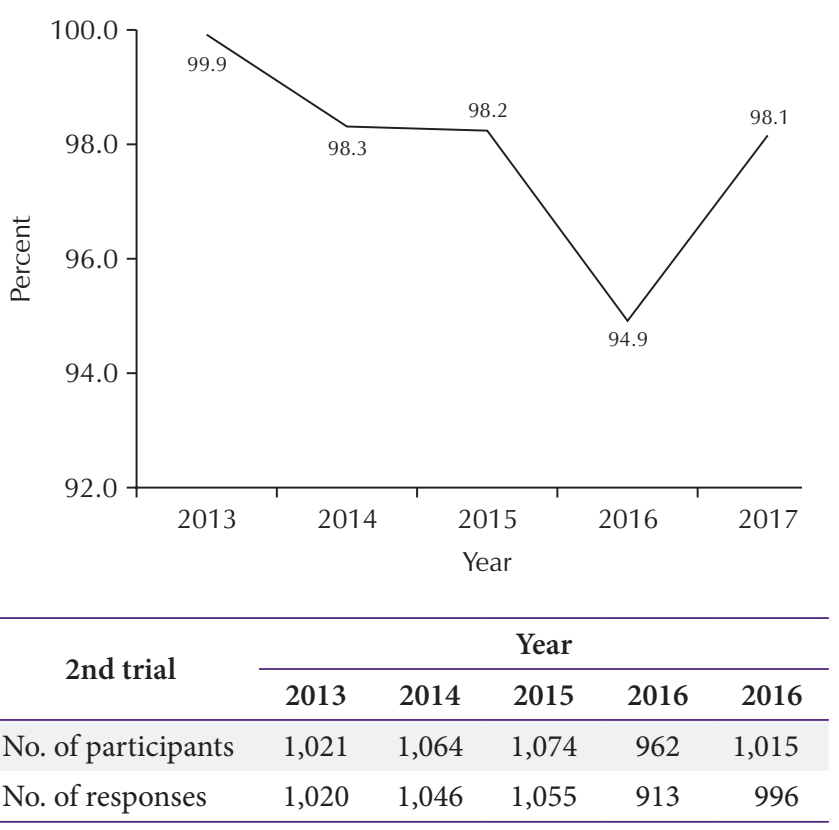

Fig. 1. Changes in response in the second trial of viral markers proficiency testing.

에서 사용한 검사방법을 정리해보면, $\mathrm{HbsAg}$ 및 anti-HBs 검사는 2016 년도에 각각 $81.5 \%$ 의 기관, 2017 년도에 각각 $76.9 \%, 77.0 \%$ 의 기관, anti-HBc total 및 anti-HBc IgM 검사는 2016년 및 2017년도에 전기관에서, $\mathrm{HbeAg}$ 및 antiHbe검사는 2016년도에 각각 $94.0 \%$ 와 $99.1 \%$ 의 기관, 2017 년도에 각각 $94.1 \%$ 와 $99.1 \%$ 의 기관, anti-HCV검사는 2016 년도에 $77.0 \%$ 기관, 2017 년도에 $74.7 \%$ 기관, anti-HAV total, anti-HAV IgG 및 anti-HAV IgM검사는 2016년도 에 각각 $100.0 \%, 96.3 \%, 97.5 \%$ 의 기관, 2017 년도에 각 각 $99.4 \%, 96.6 \%, 97.9 \%$ 의 기관이 화학발광면역검사법 (chemiluminescence immunoassay, CLIA), 전기화학발 광면역검사법(electrochemiluminescence immunoassay, ECLIA), 효소면역검사법(enzyme immunoassay, EIA), 형광효소면역검사법(fluorescence enzyme immunoassay, FEIA) 및 미세입자효소면역검사법(microparticle enzyme immunoassay, MEIA) 등 민감도가 우수한 자동화 검사법 으로 검사를 실시하고 있었다. 정성분석법인 면역크로마토그 래피법(immunochromatographic assay, ICA)은 HbsAg 및 anti-HBs검사는 2016년도에 각각 $18.5 \%$ 의 기관, 2017 년도 에 각각 $23.1 \%, 23.0 \%$ 의 기관이, $\mathrm{HbeAg}$ 및 anti-Hbe검사 는 2016 년도에 각각 $6.0 \%$ 와 $0.9 \%$ 의 기관, 2017 년도에 각각 $5.9 \%$ 와 $0.9 \%$ 의 기관, anti-HCV검사는 2016년도에 $23.0 \%$ 기관, 2017년도에 $25.3 \%$ 기관, anti-HAV total, anti-HAV 


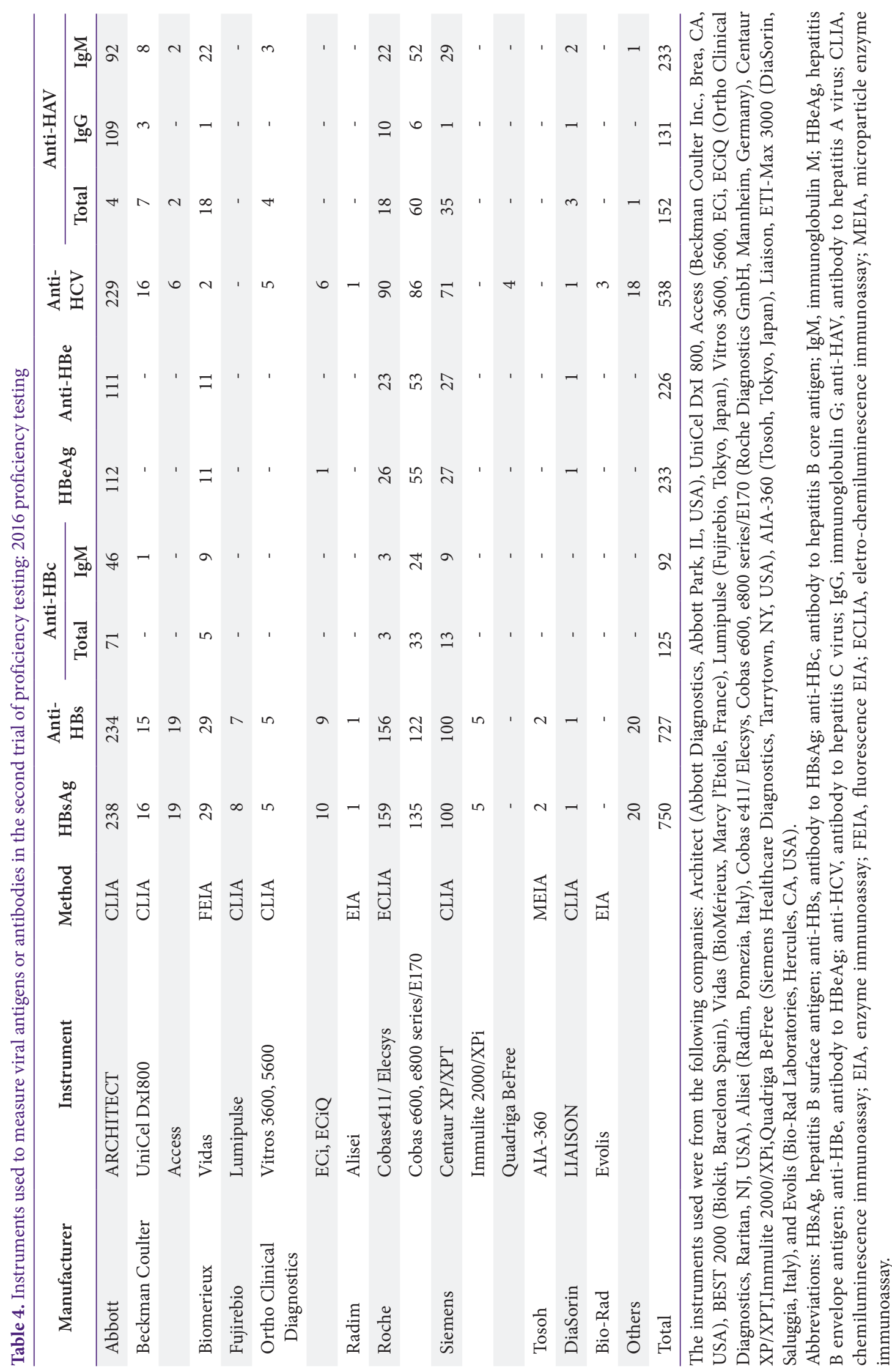




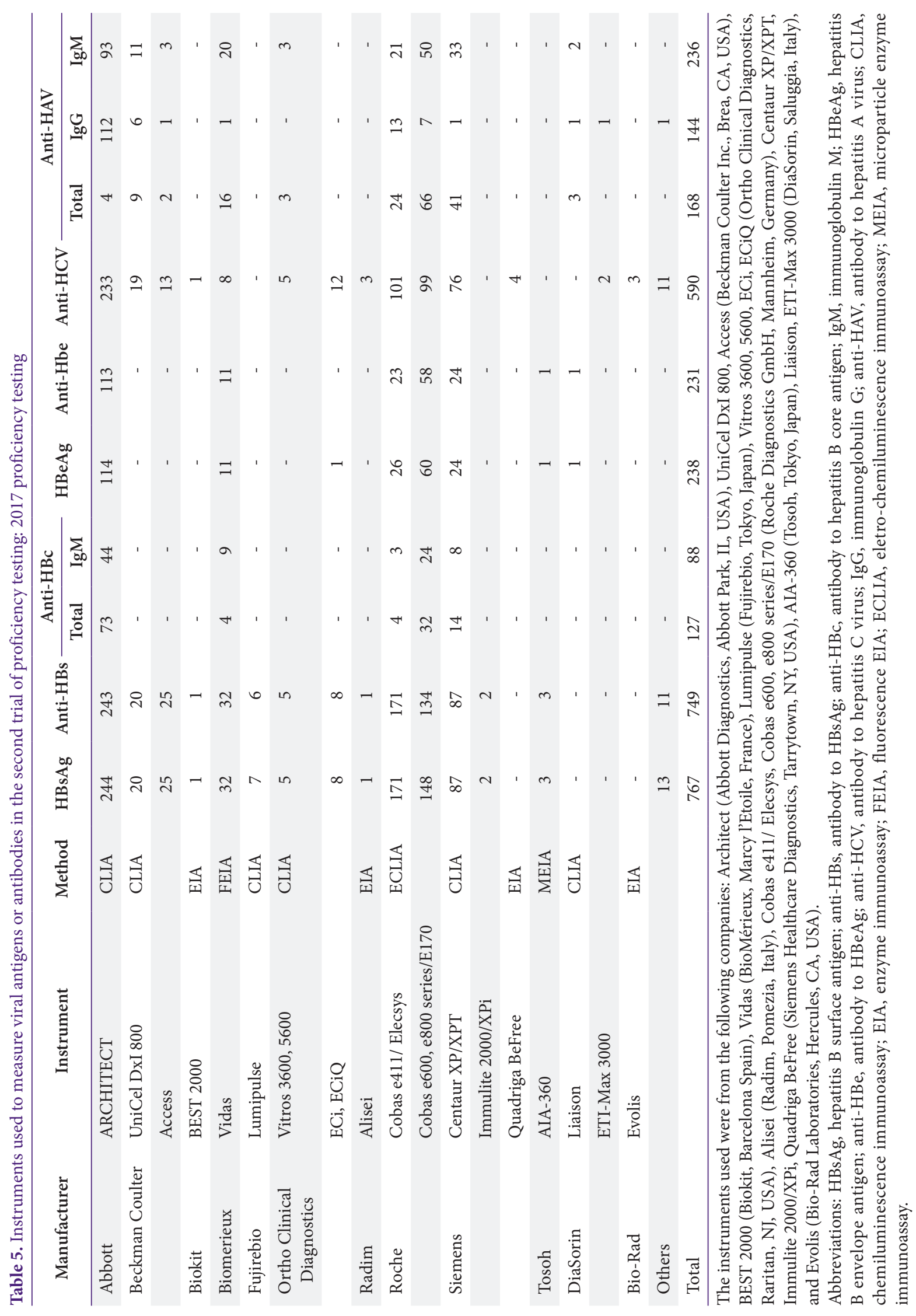




\section{Journal of LABORATORY MEDICINE and QUALITY ASSURANCE}

\section{Eun-Jung Cho et al • Report on EQA for Hepatitis Viral Markers}

IgG 및 anti-HAV IgM검사는 2016년도에 anti-HAV total검 사를 제외하고 각각 $3.7 \%, 2.5 \%$ 의 기관에서, 2017 년도에 각 각 $0.6 \%, 3.4 \%, 2.1 \%$ 의 기관에서 사용되고 있었다(Table 3 ).

검사장비별로 분류해보면 CLIA장비로는 Abbott사(Abbott Diagnostics, Abbott Park, IL, USA)의 Architect, Roche 사(Roche Diagnostics GmbH, Mannheim, Germany) 의 Cobas e411/Elecsys과 Cobas e600, e800 series/E170, Siemens사(Siemens Healthcare Diagnostics, Tarrytown, $\mathrm{NY}, \mathrm{USA}$ )의 ADVIA Centaur XP/XPT 등이 많이 사용되 고 있었고, EIA장비로는 BioMérieux사(BioMérieux, Marcy l'Etoile, France)의 VIDAS 장비가 많이 사용되고 있었다 (Tables 4, 5).

\section{3. 종목별 결과분석}

1) $B$ 형간염표면항원

$\mathrm{HBsAg}$ 검사에 대한 신빙도조사의 회신결과를 분석하면, 2016년 1차의 IL-16-02 검체와 2차의 IL-16-04 검체는 양 성 검체로서 각각 914 기관 중 $99.1 \%$ (906기관), 913 기관 중 99.1\% (905기관)에서 정답을 보고하였다(Table 6). 한편 1 차의 IL-16-01 검체와 2차의 IL-16-03과 IL-16-05 검체는 음 성 검체로서 1 차 결과 915 기관 중 899 기관에서 음성으로 보고 하여 $98.3 \%$ 의 일치율을, 2 차 결과 각각 912 기관 중 904 기관, 913기관 중 906기관에서 음성으로 보고하여 각각 $99.1 \%$ 와 $99.2 \%$ 의 높은 일치율을 보였다(Table 6). 2017년 1차의 IL17-02 검체와 2차의 IL-17-05 검체는 양성 검체로서 각각 920 기관 중 99.2\% (913기관), 996기관 중 99.7\% (993기관)에서 정답을 보고하였다(Table 7). 한편 1차의 IL-17-01 검체와 2
차의 IL-17-06 검체는 음성 검체로서 각각 920기관 중 915기 관, 996 기관 중 992 기관에서 음성으로 보고하여 각각 $99.5 \%$ 와 $99.6 \%$ 의 높은 일치율을 보였다(Table 7).

\section{2) $B$ 형간염표면항체}

Anti-HBs검사에 대한 신빙도조사의 분석결과, 2016년 1차 의 IL-16-01 검체와 2차의 IL-16-05 검체는 양성 검체로 각 각 886 기관 중 849 기관, 885 기관 중 870 기관에서 양성으로 보 고하여 각각 $95.8 \%$ 와 $98.3 \%$ 의 일치율을 보였다(Table 8 ). 한편 1차의 IL-16-02 검체와 2차의 IL-16-03과 IL-16-04 검 체는 음성 검체로 1 차 결과 886 기관 중 876 기관 기관에서 음 성으로 보고하여 $98.9 \%$ 의 일치율을, 2 차 결과 각각 884 기관 중 868 기관, 885 기관 중 874 기관에서 음성으로 보고하여 각 각 $98.2 \%$ 와 $98.8 \%$ 의 높은 일치율을 보였다(Table 8). 2017 년 1차의 IL-17-01 검체와 2차의 IL-17-06 검체는 양성 검체 로서 각각 893 기관 중 884 기관, 970 기관 중 966 기관에서 양성 으로 보고하여 각각 $99.0 \%$ 와 $99.6 \%$ 의 높은 일치율을 보였다 (Table 9). 한편 1차의 IL-17-02 검체와 2차의 IL-17-05 검체 는 음성 검체로서 각각 893 기관 중 889기관, 970 기관 중 969 기관에서 음성으로 보고하여 각각 $99.6 \%$ 와 $99.9 \%$ 의 높은 일 치율을 보였다(Table 9).

\section{3) B형간염중심항체}

Anti-HBc total검사에 대한 신빙도조사 결과, 2016년 1 차의 $\mathrm{IL}-16-01$ 과 $\mathrm{IL}-16-02$ 검체와 2차의 $\mathrm{IL}-16-04$ 과 $\mathrm{IL}-16-$ 05 검체는 양성 검체로 1 차 결과 각각 125 기관 중 124 기관, 125 기관 중 123 기관에서 양성으로 보고하여 각각 $99.2 \%$ 와

Table 6. Results of 2016 HBsAg proficiency testing

\begin{tabular}{|c|c|c|c|c|c|c|c|c|c|c|}
\hline \multirow{3}{*}{ Method } & \multicolumn{4}{|c|}{ 1st trial } & \multicolumn{6}{|c|}{ 2nd trial } \\
\hline & \multicolumn{2}{|c|}{ IL-16-01 } & \multicolumn{2}{|c|}{ IL-16-02 } & \multicolumn{2}{|c|}{ IL-16-03 } & \multicolumn{2}{|c|}{ IL-16-04 } & \multicolumn{2}{|c|}{ IL-16-05 } \\
\hline & $\mathrm{N}$ & $\mathrm{P}$ & $\mathrm{N}$ & $\mathrm{P}$ & $\mathrm{N}$ & $\mathrm{P}$ & $\mathrm{N}$ & $\mathbf{P}$ & $\mathbf{N}$ & $\mathrm{P}$ \\
\hline CLIA & 397 & 5 & 2 & 400 & 402 & - & 1 & 401 & 400 & 2 \\
\hline ECLIA & 284 & 10 & 3 & 290 & 287 & 6 & 4 & 290 & 291 & 3 \\
\hline EIA & 2 & - & 1 & 1 & 1 & - & - & 1 & 1 & - \\
\hline FEIA & 32 & - & - & 32 & 29 & & 1 & 28 & 28 & 1 \\
\hline ICA & 163 & - & 2 & 161 & 163 & 2 & 1 & 164 & 164 & 1 \\
\hline MEIA & 2 & - & - & 2 & 2 & - & - & 2 & 2 & - \\
\hline Others & 19 & 1 & - & 20 & 20 & & 1 & 19 & 20 & - \\
\hline Total & 899 & 16 & 8 & 906 & 904 & 8 & 8 & 905 & 906 & 7 \\
\hline
\end{tabular}

Abbreviations: HBsAg, hepatitis B surface antigen; N, negative; P, positive; CLIA, chemiluminescence immunoassay; ECLIA, electrochemiluminescence immunoassay; EIA, enzyme immunoassay; FEIA, fluorescence enzyme immunoassay; ICA, immunochromatography assay; MEIA, microparticle enzyme immunoassay. 
Journal of LABORATORY MEDICINE and QUALITY ASSURANCE

Eun-Jung Cho et al • Report on EQA for Hepatitis Viral Markers

Table 7. Results of 2017 HBsAg proficiency testing

\begin{tabular}{|c|c|c|c|c|c|c|c|c|}
\hline \multirow{3}{*}{ Method } & \multicolumn{4}{|c|}{ 1st trial } & \multicolumn{4}{|c|}{ 2nd trial } \\
\hline & \multicolumn{2}{|c|}{ IL-17-01 } & \multicolumn{2}{|c|}{ IL-17-02 } & \multicolumn{2}{|c|}{ IL-17-05 } & \multicolumn{2}{|c|}{ IL-17-06 } \\
\hline & $\mathrm{N}$ & $P$ & $\mathbf{N}$ & $P$ & $\mathrm{~N}$ & $P$ & $\mathrm{~N}$ & $P$ \\
\hline CLIA & 394 & 1 & 2 & 393 & 1 & 400 & 401 & - \\
\hline ECLIA & 296 & 4 & 3 & 297 & 1 & 318 & 316 & 3 \\
\hline EIA & 2 & - & - & 2 & - & 2 & 2 & - \\
\hline FEIA & 31 & - & - & 31 & - & 32 & 32 & - \\
\hline ICA & 181 & - & 2 & 179 & 1 & 226 & 226 & 1 \\
\hline MEIA & 1 & - & - & 1 & - & 3 & 3 & - \\
\hline Others & 10 & - & - & 10 & - & 12 & 12 & - \\
\hline Total & 915 & 5 & 7 & 913 & 3 & 993 & 992 & 4 \\
\hline
\end{tabular}

Abbreviations: HBsAg, hepatitis B surface antigen; N, negative; P, positive; CLIA, chemiluminescence immunoassay; ECLIA, electrochemiluminescence immunoassay; EIA, enzyme immunoassay; FEIA, fluorescence enzyme immunoassay; ICA, immunochromatography assay; MEIA, microparticle enzyme immunoassay.

Table 8. Results of 2016 anti-HBs proficiency testing

\begin{tabular}{|c|c|c|c|c|c|c|c|c|c|c|}
\hline \multirow{3}{*}{ Method } & \multicolumn{4}{|c|}{ 1st trial } & \multicolumn{6}{|c|}{ 2nd trial } \\
\hline & \multicolumn{2}{|c|}{ IL-16-01 } & \multicolumn{2}{|c|}{ IL-16-02 } & \multicolumn{2}{|c|}{ IL-16-03 } & \multicolumn{2}{|c|}{ IL-16-04 } & \multicolumn{2}{|c|}{ IL-16-05 } \\
\hline & $\mathrm{N}$ & $P$ & $\mathrm{~N}$ & $P$ & $\mathrm{~N}$ & $P$ & $\mathrm{~N}$ & $P$ & $\mathrm{~N}$ & $P$ \\
\hline CLIA & 3 & 394 & 394 & 3 & 380 & 15 & 390 & 5 & 2 & 393 \\
\hline ECLIA & 4 & 273 & 270 & 6 & 277 & - & 275 & 3 & 4 & 274 \\
\hline EIA & - & 1 & 1 & - & 1 & - & 1 & - & - & 1 \\
\hline FEIA & - & 32 & 32 & - & 29 & - & 28 & 1 & 1 & 28 \\
\hline ICA & 26 & 131 & 157 & - & 159 & 1 & 158 & 2 & 6 & 154 \\
\hline MEIA & - & 2 & 2 & - & 2 & - & 2 & - & - & 2 \\
\hline Others & 4 & 16 & 20 & - & 20 & - & 20 & - & 2 & 18 \\
\hline Total & 37 & 849 & 876 & 9 & 868 & 16 & 874 & 11 & 15 & 870 \\
\hline
\end{tabular}

Abbreviations: Anti-HBs, antibody to hepatitis B surface antigen; N, negative; P, positive; CLIA, chemiluminescence immunoassay; ECLIA, electro-chemiluminescence immunoassay; EIA, enzyme immunoassay; FEIA, fluorescence enzyme immunoassay; ICA, immunochromatography assay; MEIA, microparticle enzyme immunoassay.

$98.4 \%$ 의 일치율을 보였다. 2 차 결과 각각 125 기관 중 123 기 관, 125 기관 중 124 기관에서 양성으로 보고하여 각각 $98.4 \%$ 와 $99.2 \%$ 의 높은 일치율을 보였다(Table 10). 한편 2차의 $\mathrm{IL}^{-}$ 16-03 검체는 음성 검체로 125 기관 중 124 기관에서 음성으로 보고하여 99.2\%의 일치율을 보였다(Table 10). 2017년 1차의 IL-17-02 검체와 2차의 IL-17-05 검체는 양성 검체로서 각각 125 기관 중 124 기관, 127 기관 중 127 기관에서 양성으로 보고 하여 각각 $99.2 \%$ 와 $100.0 \%$ 의 일치율을 보였다(Table 11). 한 편 1차의 IL-17-01 검체와 2차의 IL-17-06 검체는 음성 검체 로서 각각 125 기관 중 125 기관, 127 기관 중 127 기관에서 음성 으로 보고하여 모두 $100.0 \%$ 의 일치율을 보였다(Table 11).

Anti-HBc IgM검사에 대한 신빙도조사 결과, 2016년 1차
의 $\mathrm{IL}-16-01$ 과 $\mathrm{IL}-16-02$ 검체와 2 차의 $\mathrm{IL}-16-03, \mathrm{IL}-16-04$ 와 IL-16-05 검체는 모두 음성 검체였다. 1 차 결과 각각 92 기 관 중 90 기관, 92 기관 중 92 기관에서 음성으로 보고하여 각각 $97.8 \%$ 와 $100.0 \%$ 의 일치율을 보였다. 2 차 결과 각각 92 기관 중 92기관, 91 기관, 91 기관에서 음성으로 보고하여 $100.0 \%$, $98.9 \%, 98.9 \%$ 의 높은 일치율을 보였다(Table 12). 2017년 1 차의 IL-17-01, IL-17-02 검체와 2차의 IL-17-05, IL-1706 검체는 모두 음성 검체로서 1 차 결과 각각 89 기관 중 89 기 관, 2 차 결과 88 기관 중 88 기관에서 음성으로 보고하여 모두 $100.0 \%$ 의 일치율을 보였다(Table 13). 
Journal of LABORATORY MEDICINE and QUALITY ASSURANCE

Eun-Jung Cho et al • Report on EQA for Hepatitis Viral Markers

Table 9. Results of 2017 anti-HBs proficiency testing

\begin{tabular}{|c|c|c|c|c|c|c|c|c|}
\hline \multirow{3}{*}{ Method } & \multicolumn{4}{|c|}{ 1st trial } & \multicolumn{4}{|c|}{ 2nd trial } \\
\hline & \multicolumn{2}{|c|}{ IL-17-01 } & \multicolumn{2}{|c|}{ IL-17-02 } & \multicolumn{2}{|c|}{ IL-17-05 } & \multicolumn{2}{|c|}{ IL-17-06 } \\
\hline & $\mathrm{N}$ & $P$ & $\mathrm{~N}$ & $\mathrm{P}$ & $\mathrm{N}$ & $\mathrm{P}$ & $\mathrm{N}$ & $\mathbf{P}$ \\
\hline CLIA & - & 389 & 388 & 1 & 396 & - & 1 & 395 \\
\hline ECLIA & 3 & 280 & 280 & 3 & 304 & 1 & 2 & 303 \\
\hline EIA & - & 2 & 2 & - & 2 & - & - & 2 \\
\hline FEIA & - & 31 & 31 & - & 32 & - & - & 32 \\
\hline ICA & 4 & 173 & 177 & - & 221 & - & 1 & 220 \\
\hline MEIA & - & 1 & 1 & - & 3 & - & - & 3 \\
\hline Others & 2 & 8 & 10 & - & 11 & - & - & 11 \\
\hline Total & 9 & 884 & 889 & 4 & 969 & 1 & 4 & 966 \\
\hline
\end{tabular}

Abbreviations: Anti-HBs, antibody to hepatitis B surface antigen; N, negative; P, positive; CLIA, chemiluminescence immunoassay; ECLIA, electro-chemiluminescence immunoassay; EIA, enzyme immunoassay; FEIA, fluorescence enzyme immunoassay; ICA, immunochromatography assay; MEIA, microparticle enzyme immunoassay.

Table 10. Results of 2016 anti-HBc total proficiency testing

\begin{tabular}{|c|c|c|c|c|c|c|c|c|c|c|}
\hline \multirow{3}{*}{ Method } & \multicolumn{4}{|c|}{ 1st trial } & \multicolumn{6}{|c|}{ 2nd trial } \\
\hline & \multicolumn{2}{|c|}{ IL-16-01 } & \multicolumn{2}{|c|}{ IL-16-02 } & \multicolumn{2}{|c|}{ IL-16-03 } & \multicolumn{2}{|c|}{ IL-16-04 } & \multicolumn{2}{|c|}{ IL-16-05 } \\
\hline & $\mathrm{N}$ & $\mathrm{P}$ & $\mathrm{N}$ & $\mathbf{P}$ & $\mathrm{N}$ & $\mathrm{P}$ & $\mathrm{N}$ & $\mathrm{P}$ & $\mathrm{N}$ & $\mathrm{P}$ \\
\hline CLIA & - & 83 & 1 & 82 & 84 & - & - & 84 & - & 84 \\
\hline ECLIA & 1 & 36 & 1 & 36 & 35 & - & - & 35 & - & 35 \\
\hline EIA & - & - & - & - & - & - & - & - & - & - \\
\hline FEIA & - & 5 & - & 5 & 5 & - & 1 & 4 & - & 5 \\
\hline ICA & - & - & - & - & - & - & - & - & - & - \\
\hline MEIA & - & - & - & - & - & - & - & - & - & - \\
\hline Others & - & - & - & - & - & - & - & - & - & - \\
\hline Total & 1 & 124 & 2 & 123 & 124 & - & 1 & 123 & - & 124 \\
\hline
\end{tabular}

Abbreviations: Anti-HBc, antibody to hepatitis core antigen; N, negative; P, positive; CLIA, chemiluminescence immunoassay; ECLIA, electrochemiluminescence immunoassay; EIA, enzyme immunoassay; FEIA, fluorescence enzyme immunoassay; ICA, immunochromatography assay; MEIA, microparticle enzyme immunoassay.

\section{4) $B$ 형간염외피항원}

$\mathrm{HBeAg}$ 검사에 대한 신빙도조사 결과, 2016년 2차의 IL-1604 검체는 양성 검체로 248 기관 중 233 기관에서 양성으로 보 고하여 $94.0 \%$ 의 일치율을 보였다(Table 14). 1차의 IL-1601과 IL-16-02 검체와 2차의 IL-16-03과 IL-16-05 검체는 음 성 검체였다. 1 차 결과 각각 249 기관 중 247 기관, 249 기관 중 220 기관에서 음성으로 보고하여 각각 $99.2 \%$ 와 $88.4 \%$ 의 일 치율을, 2 차 결과 각각 248 기관 중 248 기관, 248 기관 중 248 기관에서 음성으로 보고하여 모두 $100.0 \%$ 의 일치율을 보였 다(Table 14). 2017년 2차의 IL-17-05 검체는 양성 검체로서
각각 253 기관 중 239 기관에서 양성으로 보고하여 $94.5 \%$ 의 일치율을 보였다(Table 15). 한편 1차의 IL-17-01, IL-17-02 검체와 2차의 IL-17-06 검체는 음성 검체로서 1차 결과 각각 250 기관 중 250 기관, 250 기관 중 248 기관에서 음성으로 보고 하여 각각 $100.0 \%$ 와 $99.2 \%$ 의 일치율을, 2 차 결과 253 기관 중 252 기관에서 음성으로 보고하여 $99.6 \%$ 의 높은 일치율을 보였 다(Table 15).

\section{5) B형간염외피항체}

Anti-HBe검사에 대한 신빙도조사 결과, 2016년 1차의 IL- 


\section{Journal of LABORATORY MEDICINE and QUALITY ASSURANCE}

\section{Eun-Jung Cho et al • Report on EQA for Hepatitis Viral Markers}

Table 11. Results of 2017 anti-HBc total proficiency testing

\begin{tabular}{|c|c|c|c|c|c|c|c|c|}
\hline \multirow{3}{*}{ Method } & \multicolumn{4}{|c|}{ 1st trial } & \multicolumn{4}{|c|}{ 2nd trial } \\
\hline & \multicolumn{2}{|c|}{ IL-17-01 } & \multicolumn{2}{|c|}{ IL-17-02 } & \multicolumn{2}{|c|}{ IL-17-05 } & \multicolumn{2}{|c|}{ IL-17-06 } \\
\hline & $\mathrm{N}$ & $\mathrm{P}$ & $\mathrm{N}$ & $\mathrm{P}$ & $\mathrm{N}$ & $\mathbf{P}$ & $\mathrm{N}$ & $\mathrm{P}$ \\
\hline CLIA & 83 & - & - & 83 & - & 87 & 87 & - \\
\hline ECLIA & 36 & - & 1 & 35 & - & 36 & 36 & - \\
\hline EIA & & - & - & - & - & - & - & - \\
\hline FEIA & 5 & - & - & 5 & - & 4 & 4 & - \\
\hline ICA & - & - & - & - & - & - & - & - \\
\hline MEIA & - & - & - & - & - & - & - & - \\
\hline Others & 1 & - & - & 1 & - & - & - & - \\
\hline Total & 125 & - & 1 & 124 & - & 127 & 127 & - \\
\hline
\end{tabular}

Abbreviations: Anti-HBc, antibody to hepatitis core antigen; N, negative; P, positive; CLIA, chemiluminescence immunoassay; ECLIA, electrochemiluminescence immunoassay; EIA, enzyme immunoassay; FEIA, fluorescence enzyme immunoassay; ICA, immunochromatography assay; MEIA, microparticle enzyme immunoassay.

Table 12. Results of 2016 anti-HBc immunoglobulin M proficiency testing

\begin{tabular}{|c|c|c|c|c|c|c|c|c|c|c|}
\hline \multirow{3}{*}{ Method } & \multicolumn{4}{|c|}{ 1st trial } & \multicolumn{6}{|c|}{ 2nd trial } \\
\hline & \multicolumn{2}{|c|}{ IL-16-01 } & \multicolumn{2}{|c|}{ IL-16-02 } & \multicolumn{2}{|c|}{ IL-16-03 } & \multicolumn{2}{|c|}{ IL-16-04 } & \multicolumn{2}{|c|}{ IL-16-05 } \\
\hline & $\mathrm{N}$ & $\mathbf{P}$ & $\mathrm{N}$ & $\mathbf{P}$ & $\mathrm{N}$ & $\mathbf{P}$ & $\mathrm{N}$ & $\mathbf{P}$ & $\mathrm{N}$ & $\mathrm{P}$ \\
\hline CLIA & 55 & 1 & 56 & - & 56 & - & 55 & 1 & 55 & 1 \\
\hline ECLIA & 26 & 1 & 27 & - & 27 & - & 27 & - & 27 & - \\
\hline EIA & - & - & - & - & - & - & - & - & - & - \\
\hline FEIA & 9 & 0 & 9 & - & 9 & - & 9 & - & 9 & - \\
\hline ICA & - & - & - & - & - & - & - & - & - & - \\
\hline MEIA & - & - & - & - & - & - & - & - & - & - \\
\hline Others & - & - & - & - & - & - & - & - & - & - \\
\hline Total & 90 & 2 & 92 & - & 92 & - & 91 & 1 & 91 & 1 \\
\hline
\end{tabular}

Abbreviations: Anti-HBc, antibody to hepatitis core antigen; N, negative; P, positive; CLIA, chemiluminescence immunoassay; ECLIA, electrochemiluminescence immunoassay; EIA, enzyme immunoassay; FEIA, fluorescence enzyme immunoassay; ICA, immunochromatography assay; MEIA, microparticle enzyme immunoassay.

16-01과 IL-16-02 검체는 양성 검체로 각각 227기관 중 221 기관, 227 기관 중 224 기관에서 양성으로 보고하여 $97.4 \%$ 와 $98.7 \%$ 의 일치율을 보였다(Table 16). 한편 2차의 IL-16-03, IL-16-04와 IL- $16-05$ 검체는 음성 검체로 각각 228 기관 중 228 기관, 226 기관, 224 기관에서 음성으로 보고하여 $100.0 \%$, $99.1 \%, 98.2 \%$ 의 일치율을 보였다(Table 16). 2017년 1차의 IL-17-02 검체는 양성 검체로서 231기관 중 225기관에서 양 성으로 보고하여 $97.4 \%$ 의 일치율을 보였다(Table 17). 한편 1 차의 IL-17-01 검체와 2차의 IL-17-05, IL-17-06 검체는 음 성 검체로서 1차 결과 231기관 중 227기관에서 음성으로 보고
하여 $98.3 \%$ 의 일치율을, 2 차 결과 각각 233 기관 중 233 기관, 233기관 중 233기관에서 음성으로 보고하여 모두 $100.0 \%$ 의 높은 일치율을 보였다(Table 17).

\section{6) C형간염항체}

Anti-HCV검사에 대한 신빙도조사 결과, 2016년 1차의 IL16 -01 검체와 2차의 IL- $16-03$ 검체는 양성 검체로 각각 689기 관 중 682 기관, 692 기관 중 683 기관에서 양성으로 보고하여 각각 $99.0 \%$ 와 $98.7 \%$ 의 높은 일치율을 보였다(Table 18). 한 편 1차의 IL-16-02 검체와 2차의 IL-16-04와 IL-16-05 검체는 


\section{Journal of LABORATORY MEDICINE and QUALITY ASSURANCE}

\section{Eun-Jung Cho et al • Report on EQA for Hepatitis Viral Markers}

Table 13. Results of 2017 anti-HBc immunoglobulin M proficiency testing

\begin{tabular}{|c|c|c|c|c|c|c|c|c|}
\hline \multirow{3}{*}{ Method } & \multicolumn{4}{|c|}{ 1st trial } & \multicolumn{4}{|c|}{ 2nd trial } \\
\hline & \multicolumn{2}{|c|}{ IL-17-01 } & \multicolumn{2}{|c|}{ IL-17-02 } & \multicolumn{2}{|c|}{ IL-17-05 } & \multicolumn{2}{|c|}{ IL-17-06 } \\
\hline & $\mathbf{N}$ & $\mathrm{P}$ & $\mathrm{N}$ & $\mathrm{P}$ & $\mathrm{N}$ & $\mathrm{P}$ & $\mathrm{N}$ & $\mathrm{P}$ \\
\hline CLIA & 53 & - & 53 & - & 52 & - & 52 & - \\
\hline ECLIA & 27 & - & 27 & - & 27 & - & 27 & - \\
\hline EIA & - & - & - & - & - & - & - & - \\
\hline FEIA & 9 & - & 9 & - & 9 & - & 9 & - \\
\hline ICA & - & - & - & - & - & - & - & - \\
\hline MEIA & - & - & - & - & - & - & - & - \\
\hline Others & - & - & - & - & - & - & - & - \\
\hline Total & 89 & - & 89 & - & 88 & - & 88 & - \\
\hline
\end{tabular}

Abbreviations: Anti-HBc, antibody to hepatitis core antigen; N, negative; P, positive; CLIA, chemiluminescence immunoassay; ECLIA, electrochemiluminescence immunoassay; EIA, enzyme immunoassay; FEIA, fluorescence enzyme immunoassay; ICA, immunochromatography assay; MEIA, microparticle enzyme immunoassay.

Table 14. Results of $2016 \mathrm{HBeAg}$ proficiency testing

\begin{tabular}{|c|c|c|c|c|c|c|c|c|c|c|}
\hline \multirow{3}{*}{ Method } & \multicolumn{4}{|c|}{ 1st trial } & \multicolumn{6}{|c|}{ 2nd trial } \\
\hline & \multicolumn{2}{|c|}{ IL-16-01 } & \multicolumn{2}{|c|}{ IL-16-02 } & \multicolumn{2}{|c|}{ IL-16-03 } & \multicolumn{2}{|c|}{ IL-16-04 } & \multicolumn{2}{|c|}{ IL-16-05 } \\
\hline & $\mathrm{N}$ & $P$ & $\mathrm{~N}$ & $P$ & $\mathrm{~N}$ & $P$ & $\mathrm{~N}$ & $P$ & $\mathrm{~N}$ & $\mathrm{P}$ \\
\hline CLIA & 138 & - & 112 & 26 & 141 & - & - & 141 & 141 & - \\
\hline ECLIA & 82 & - & 82 & - & 81 & - & 1 & 80 & 81 & - \\
\hline EIA & - & - & - & - & - & - & - & - & - & - \\
\hline FEIA & 11 & - & 11 & - & 11 & - & - & 11 & 11 & - \\
\hline ICA & 16 & 2 & 15 & 3 & 15 & - & 14 & 1 & 15 & - \\
\hline MEIA & - & - & - & - & - & - & - & - & - & - \\
\hline Others & - & - & - & - & - & - & - & - & - & - \\
\hline Total & 247 & 2 & 220 & 29 & 248 & - & 15 & 233 & 248 & - \\
\hline
\end{tabular}

Abbreviations: HBeAg, hepatitis B envelope antigen; N, negative; P, positive; CLIA, chemiluminescence immunoassay; ECLIA, electrochemiluminescence immunoassay; EIA, enzyme immunoassay; FEIA, fluorescence enzyme immunoassay; ICA, immunochromatography assay; MEIA, microparticle enzyme immunoassay.

음성 검체로 1 차 결과 689 기관 중 559 기관에서 음성으로 보 고하여 $81.1 \%$ 의 일치율을, 2 차 결과 각각 693 기관 중 690 기 관, 693 기관 중 686 기관에서 음성으로 보고하여 각각 $99.6 \%$, $99.0 \%$ 의 일치율을 보였다(Table 18). 2017년 1차의 IL-17-04 검체와 2차의 IL-17-08 검체는 양성 검체로서 각각 707 기관 중 706 기관, 783 기관 중 781 기관에서 양성으로 보고하여 각 각 $99.9 \%$ 와 $99.7 \%$ 의 일치율을 보였다(Table 19). 한편 1차의 IL-17-03 검체와 2차의 IL-17-07 검체는 음성 검체로서 각각 707 기관 중 706 기관, 783 기관 중 783 기관에서 음성으로 보고 하여 각각 $99.9 \%$ 와 $100.0 \%$ 의 일치율을 보였다(Table 19).

\section{7) A형간염항체}

2016년 anti-HAV 검사에 대한 신빙도조사 결과, antiHAV IgM검사를 시행하는 기관 수는 239개 기관으로 anti$\mathrm{HAV}$ 검사 중에서 가장 많았으며, 이 중 110 개의 기관(46.0\%) 은 anti-HAV IgM과 total검사를, 102 개의 기관(42.7\%)은 anti-HAV IgM과 $\operatorname{IgG}$ 검사를 동시에 시행하고 있었다. 5개의 기관(2.1\%)이 anti-HAV IgM, IgG 및 total검사를 모두 시행 하고 있었다. 2017년 신빙도조사 결과, anti-HAV IgM검사를 시행하는 기관 수는 241 개 기관으로 anti-HAV검사 중에서 가 장 많았으며, 이 중 116 개의 기관(48.1\%)은 anti-HAV IgM 과 total검사를 동시에 시행하고 있었다. 99개의 기관(41.1\%) 이 anti-HAV IgG과 total검사를, 6 개의 기관(2.5\%)이 anti- 
Journal of LABORATORY MEDICINE and QUALITY ASSURANCE

Eun-Jung Cho et al • Report on EQA for Hepatitis Viral Markers

Table 15. Results of 2017 HBeAg proficiency testing

\begin{tabular}{|c|c|c|c|c|c|c|c|c|}
\hline \multirow{3}{*}{ Method } & \multicolumn{4}{|c|}{ 1st trial } & \multicolumn{4}{|c|}{ 2nd trial } \\
\hline & \multicolumn{2}{|c|}{ IL-17-01 } & \multicolumn{2}{|c|}{ IL-17-02 } & \multicolumn{2}{|c|}{ IL-17-05 } & \multicolumn{2}{|c|}{ IL-17-06 } \\
\hline & $\mathrm{N}$ & $\mathrm{P}$ & $\mathrm{N}$ & $P$ & $\mathrm{~N}$ & $P$ & $\mathrm{~N}$ & $\mathrm{P}$ \\
\hline CLIA & 139 & - & 138 & 1 & - & 140 & 139 & 1 \\
\hline ECLIA & 85 & - & 85 & - & - & 86 & 86 & - \\
\hline EIA & - & - & - & - & - & - & - & - \\
\hline FEIA & 11 & - & 11 & - & - & 11 & 11 & - \\
\hline ICA & 14 & - & 13 & 1 & 14 & 1 & 15 & - \\
\hline MEIA & - & - & - & - & - & 1 & 1 & - \\
\hline Others & 1 & - & 1 & - & - & - & - & - \\
\hline Total & 250 & - & 248 & 2 & 14 & 239 & 252 & 1 \\
\hline
\end{tabular}

Abbreviations: HBeAg, hepatitis B envelope antigen; N, negative; P, positive; CLIA, chemiluminescence immunoassay; ECLIA, electrochemiluminescence immunoassay; EIA, enzyme immunoassay; FEIA, fluorescence enzyme immunoassay; ICA, immunochromatography assay; MEIA, microparticle enzyme immunoassay.

Table 16. Results of 2016 anti-HBe proficiency testing

\begin{tabular}{|c|c|c|c|c|c|c|c|c|c|c|}
\hline \multirow{3}{*}{ Method } & \multicolumn{4}{|c|}{ 1st trial } & \multicolumn{6}{|c|}{ 2nd trial } \\
\hline & \multicolumn{2}{|c|}{ IL-16-01 } & \multicolumn{2}{|c|}{ IL-16-02 } & \multicolumn{2}{|c|}{ IL-16-03 } & \multicolumn{2}{|c|}{ IL-16-04 } & \multicolumn{2}{|c|}{ IL-16-05 } \\
\hline & $\mathrm{N}$ & $\mathbf{P}$ & $\mathrm{N}$ & $P$ & $\mathrm{~N}$ & $P$ & $\mathrm{~N}$ & $P$ & $\mathrm{~N}$ & $\mathrm{P}$ \\
\hline CLIA & 4 & 133 & 2 & 135 & 139 & - & 138 & 1 & 138 & - \\
\hline ECLIA & - & 77 & - & 77 & 76 & - & 75 & 1 & 76 & - \\
\hline EIA & - & - & - & - & - & - & - & - & - & - \\
\hline FEIA & - & 11 & - & 11 & 11 & - & 11 & - & 9 & 2 \\
\hline ICA & 2 & - & 1 & 1 & 2 & - & 2 & - & 1 & 1 \\
\hline MEIA & - & - & - & - & - & - & - & - & - & - \\
\hline Others & - & - & - & - & - & - & - & - & - & - \\
\hline Total & 6 & 221 & 3 & 224 & 228 & - & 226 & 2 & 224 & 3 \\
\hline
\end{tabular}

Abbreviations: Anti-HBe, antibody to hepatitis B envelope antigen; N, negative; P, positive; CLIA, chemiluminescence immunoassay; ECLIA, electro-chemiluminescence immunoassay; EIA, enzyme immunoassay; FEIA, fluorescence enzyme immunoassay; ICA, immunochromatography assay; MEIA, microparticle enzyme immunoassay.

HAV IgM, IgG 및 total검사를 모두 시행하고 있었으며, 한 개 의 기관(0.4\%)이 anti-HAV IgM과 IgG검사를 시행하고 있었 다.

Anti-HAV total검사에 대한 신빙도조사 결과, 2016년 1차 의 IL-16-01, IL-16-02 검체와 2차의 IL-16-04, IL-16-05 검 체는 양성 검체로 1 차 결과 각각 151 기관 중 148 기관, 151 기 관 중 149 기관에서 양성으로 보고하여 각각 $98.0 \%, 98.7 \%$ 의 일치율을, 2 차 결과 152 기관 중 149 기관, 152 기관 중 150 기관에서 양성으로 보고하여 각각 $98.0 \%, 98.7 \% \%$ 의 일치 율을 보였다. 한편 2차의 IL-16-03검체는 음성 검체로 152 기 관 중 140 기관에서 음성으로 보고하여 $92.1 \%$ 의 일치율을 보
였다(Table 20). 2017년 1차의 IL-17-03, IL-17-04 검체와 2 차의 IL-17-08검체는 양성 검체로서 1차 결과 각각 157 기관 중 157 기관, 157 기관 중 157 기관에서 양성으로 보고하여 모두 $100.0 \%$ 의 일치율을, 2 차 결과 169 기관 중 167 기관에서 양성 으로 보고하여 $98.8 \%$ 의 일치율을 보였다. 한편 2차의 IL-1707검체는 음성 검체로서 169 기관 중 159 기관에서 음성으로 보고하여 $94.1 \%$ 의 일치율을 보였다(Table 21 ).

Anti-HAV IgG검사에 대한 신빙도조사 결과, 2016년 1차 의 IL-16-01, IL- $16-02$ 검체와 2차의 IL-16-04, IL-16-05 검 체는 양성 검체로 1 차 결과 각각 133 기관 중 133 기관, 133 기 관 중 132 기관에서 양성으로 보고하여 각각 $100.0 \%, 99.2 \%$ 


\section{Journal of LABORATORY MEDICINE and QUALITY ASSURANCE}

\section{Eun-Jung Cho et al • Report on EQA for Hepatitis Viral Markers}

의 일치율을, 2 차 결과 135 기관 중 134 기관, 135 기관 중 133 기관에서 양성으로 보고하여 각각 $99.3 \%, 98.5 \%$ 의 높은 일치 율을 보였다. 한편 2차의 IL-16-03 검체는 음성 검체로 135 기 관 중 130 기관에서 음성으로 보고하여 $96.3 \%$ 의 일치율을 보 였다(Table 22). 2017년 1차의 IL-17-03, IL-17-04 검체와 2 차의 IL-17-08 검체는 양성 검체로서 1차 결과 각각 136 기관 중 135 기관, 136 기관 중 135 기관에서 양성으로 보고하여 모두 $99.3 \%$ 의 일치율을, 2 차 결과 149 기관 중 148 기관에서 양성으 로 보고하여 $99.3 \%$ 의 일치율을 보였다. 한편 2차의 IL-17-07

Table 17. Results of 2017 anti-HBe proficiency testing

\begin{tabular}{|c|c|c|c|c|c|c|c|c|}
\hline \multirow{3}{*}{ Method } & \multicolumn{4}{|c|}{ 1st trial } & \multicolumn{4}{|c|}{ 2nd trial } \\
\hline & \multicolumn{2}{|c|}{ IL-17-01 } & \multicolumn{2}{|c|}{ IL-17-02 } & \multicolumn{2}{|c|}{ IL-17-05 } & \multicolumn{2}{|c|}{ IL-17-06 } \\
\hline & $\mathrm{N}$ & $\mathbf{P}$ & $\mathrm{N}$ & $P$ & $\mathrm{~N}$ & $\mathbf{P}$ & $\mathrm{N}$ & $\mathrm{P}$ \\
\hline CLIA & 135 & 2 & 3 & 134 & 138 & - & 138 & - \\
\hline ECLIA & 79 & 1 & 1 & 79 & 81 & - & 81 & - \\
\hline EIA & - & - & - & - & - & - & - & - \\
\hline FEIA & 11 & - & - & 11 & 11 & - & 11 & - \\
\hline ICA & 1 & 1 & 2 & - & 2 & - & 2 & - \\
\hline MEIA & - & - & - & - & 1 & - & 1 & - \\
\hline Others & 1 & - & - & 1 & - & - & - & - \\
\hline Total & 227 & 4 & 6 & 225 & 233 & - & 233 & - \\
\hline
\end{tabular}

Abbreviations: Anti-HBe, antibody to hepatitis B envelope antigen; $\mathrm{N}$, negative; $\mathrm{P}$, positive; CLIA, chemiluminescence immunoassay; ECLIA, electro-chemiluminescence immunoassay; EIA, enzyme immunoassay; FEIA, fluorescence enzyme immunoassay; ICA, immunochromatography assay; MEIA, microparticle enzyme immunoassay.
검체는 음성 검체로서 149 기관 중 148 기관에서 음성으로 보고 하여 $99.3 \%$ 의 일치율을 보였다(Table 23).

Anti-HAV IgM검사에 대한 신빙도조사 결과, 2016년 1차 의 IL-16-01, IL-16-02 검체와 2차의 IL-16-03, IL-16-04, IL-16-05 검체는 모두 음성 검체로 1 차 결과 각각 236기관 중 234 기관, 236 기관 중 232 기관에서 음성으로 보고하여 각각 $99.2 \%, 98.3 \%$ 의 일치율을 보였다. 2 차 결과 239 기관 중 238 기관에서 모두 음성으로 보고하여 $99.6 \%$ 의 일치율을 보였다 (Table 24). 2017년 1차의 IL-17-03 검체는 양성 검체로서

Table 19. Results of 2017 anti-HCV proficiency testing

\begin{tabular}{|c|c|c|c|c|c|c|c|c|}
\hline \multirow{3}{*}{ Method } & \multicolumn{4}{|c|}{ 1st trial } & \multicolumn{4}{|c|}{ 2nd trial } \\
\hline & \multicolumn{2}{|c|}{ IL-17-03 } & \multicolumn{2}{|c|}{ IL-17-04 } & \multicolumn{2}{|c|}{ IL-17-07 } & \multicolumn{2}{|c|}{ IL-17-08 } \\
\hline & $\mathbf{N}$ & $\mathrm{P}$ & $\mathrm{N}$ & $\mathrm{P}$ & $\mathrm{N}$ & $\mathrm{P}$ & $\mathbf{N}$ & $\mathbf{P}$ \\
\hline CLIA & 341 & 1 & 1 & 341 & 359 & - & 1 & 358 \\
\hline ECLIA & 185 & - & - & 185 & 200 & - & - & 200 \\
\hline EIA & 7 & - & - & 7 & 7 & - & - & 7 \\
\hline FEIA & 7 & - & - & 7 & 8 & - & - & 8 \\
\hline ICA & 159 & - & - & 159 & 198 & - & 1 & 197 \\
\hline MEIA & - & - & - & - & - & - & - & - \\
\hline Others & 7 & - & - & 7 & 11 & - & - & 11 \\
\hline Total & 706 & 1 & 1 & 706 & 783 & 0 & 2 & 781 \\
\hline
\end{tabular}

Abbreviations: Anti-HCV, anti-hepatitis $\mathrm{C}$ virus antibody; N, negative; P, positive; CLIA, chemiluminescence immunoassay; ECLIA, electro-chemiluminescence immunoassay; EIA, enzyme immunoassay; FEIA, fluorescence enzyme immunoassay; ICA, immunochromatography assay; MEIA, microparticle enzyme immunoassay.

Table 18. Results of 2016 anti-HCV proficiency testing

\begin{tabular}{|c|c|c|c|c|c|c|c|c|c|c|}
\hline \multirow{3}{*}{ Method } & \multicolumn{4}{|c|}{ 1st trial } & \multicolumn{6}{|c|}{ 2nd trial } \\
\hline & \multicolumn{2}{|c|}{ IL-16-01 } & \multicolumn{2}{|c|}{ IL-16-02 } & \multicolumn{2}{|c|}{ IL-16-03 } & \multicolumn{2}{|c|}{ IL-16-04 } & \multicolumn{2}{|c|}{ IL-16-05 } \\
\hline & $\mathrm{N}$ & $\mathrm{P}$ & $\mathrm{N}$ & $\mathbf{P}$ & $\mathrm{N}$ & $\mathrm{P}$ & $\mathrm{N}$ & $\mathrm{P}$ & $\mathrm{N}$ & $\mathrm{P}$ \\
\hline CLIA & 4 & 336 & 336 & 4 & 1 & 337 & 338 & - & 338 & - \\
\hline ECLIA & 2 & 173 & 51 & 123 & 2 & 174 & 175 & 1 & 175 & 1 \\
\hline EIA & - & 5 & 5 & - & - & 4 & 4 & - & 4 & - \\
\hline FEIA & - & 2 & 2 & - & - & 2 & 2 & - & 2 & - \\
\hline ICA & 1 & 146 & 145 & 2 & 4 & 151 & 154 & 1 & 149 & 6 \\
\hline MEIA & - & - & - & - & - & - & - & - & - & - \\
\hline Others & - & 20 & 20 & - & 2 & 15 & 17 & 1 & 18 & - \\
\hline Total & 7 & 682 & 559 & 129 & 9 & 683 & 690 & 3 & 686 & 7 \\
\hline
\end{tabular}

Abbreviations: Anti-HCV, anti-hepatitis C virus antibody; N, negative; P, positive; CLIA, chemiluminescence immunoassay; ECLIA, electrochemiluminescence immunoassay; EIA, enzyme immunoassay; FEIA, fluorescence enzyme immunoassay; ICA, immunochromatography assay; MEIA, microparticle enzyme immunoassay. 


\section{Journal of LABORATORY MEDICINE and QUALITY ASSURANCE}

\section{Eun-Jung Cho et al • Report on EQA for Hepatitis Viral Markers}

Table 20. Results of 2016 anti-HAV total proficiency testing

\begin{tabular}{|c|c|c|c|c|c|c|c|c|c|c|}
\hline \multirow{3}{*}{ Method } & \multicolumn{4}{|c|}{ 1st trial } & \multicolumn{6}{|c|}{ 2nd trial } \\
\hline & \multicolumn{2}{|c|}{ IL-16-01 } & \multicolumn{2}{|c|}{ IL-16-02 } & \multicolumn{2}{|c|}{ IL-16-03 } & \multicolumn{2}{|c|}{ IL-16-04 } & \multicolumn{2}{|c|}{ IL-16-05 } \\
\hline & $\mathrm{N}$ & $P$ & $\mathrm{~N}$ & $P$ & $\mathrm{~N}$ & $P$ & $\mathrm{~N}$ & $P$ & $\mathrm{~N}$ & $P$ \\
\hline CLIA & - & 55 & - & 55 & 52 & 3 & 1 & 54 & 1 & 54 \\
\hline ECLIA & 1 & 73 & 1 & 73 & 74 & 4 & 1 & 77 & - & 78 \\
\hline EIA & 1 & 0 & - & 1 & - & - & - & - & - & - \\
\hline FEIA & - & 18 & - & 18 & 13 & 4 & - & 18 & - & 18 \\
\hline ICA & - & 2 & - & 2 & 1 & - & 1 & - & 1 & - \\
\hline MEIA & - & - & - & - & - & - & - & - & - & - \\
\hline Others & - & - & - & - & - & - & - & - & - & - \\
\hline Total & 2 & 148 & 1 & 149 & 140 & 11 & 3 & 149 & 2 & 150 \\
\hline
\end{tabular}

Abbreviations: Anti-HAV, anti-hepatitis A virus antibody; N, negative; P, positive; CLIA, chemiluminescence immunoassay; ECLIA, electrochemiluminescence immunoassay; EIA, enzyme immunoassay; FEIA, fluorescence enzyme immunoassay; ICA, immunochromatography assay; MEIA, microparticle enzyme immunoassay.

232기관 중 213 기관에서 양성으로 보고하여 $91.8 \%$ 의 일치율 을 보였다. 한편 1차의 IL-17-04 검체와 2차의 IL-17-07, IL17-08 검체는 음성 검체로서 1 차 결과 232기관 중 229기관에 서 음성으로 보고하여 $98.7 \%$ 의 일치율을, 2 차 결과 각각 241 기관 중 241기관, 241 기관 중 241기관에서 음성으로 보고하여 모두 $100.0 \%$ 의 일치율을 보였다(Table 25).

\section{고찰}

2016년 차세대 신빙도조사사업 시행에 따라 간염바이러스 항원항체검사 신빙도조사사업은 검사 항목이 기존의 4 개에서 10 개로 증가되어 $\mathrm{A}$ 형, $\mathrm{B}$ 형 및 $\mathrm{C}$ 형 간염바이러스의 혈청학적 검사에 대한 외부정도관리가 시행되었다.

2016년 간염바이러스 항원항체검사 신빙도조사사업은 6월 과 10 월에 실시되었는데, 각각 965 기관과 962 기관에 검체를 발송하여 1, 2차에 참여한 기관이 각각 915 기관(94.8\%), 913 기관(95.0\%)으로 높은 참여율을 보였다. 2017년 신빙도조사 사업은 5 월과 10 월에 실시되었으며, 각각 936 기관과 1,015 기관에 검체를 발송하여 1,2 차에 참여한 기관이 각각 920 기 관(98.3\%), 996기관(98.1\%)으로 매우 높은 참여율을 보였 다. 2017년 참여기관은 2016년도 참여기관 수와 비교하여 53 기관(5.2\%)이 증가하였다. 신빙도조사사업에 사용되는 검체 는 2016년도는 서울아산병원에서 제조하였으며, 2017년도는 서울성모병원에서 제조하였다. Matrix effect를 배제하기 위 해 '한마음 혈액원'으로부터 혈장을 분양받아 각 종목의 양성 과 음성 신빙도조사 검체를 자가제조하였다. 제조된 검체의 정 성결과 값의 확인 및 장비 간 결과값 일치 여부를 검증하기 위
Table 21. Results of 2017 anti-HAV total proficiency testing

\begin{tabular}{|c|c|c|c|c|c|c|c|c|}
\hline \multirow{3}{*}{ Method } & \multicolumn{4}{|c|}{ 1st trial } & \multicolumn{4}{|c|}{ 2nd trial } \\
\hline & \multicolumn{2}{|c|}{ IL-17-03 } & \multicolumn{2}{|c|}{ IL-17-04 } & \multicolumn{2}{|c|}{ IL-17-07 } & \multicolumn{2}{|c|}{ IL-17-08 } \\
\hline & $\mathrm{N}$ & $P$ & $\mathrm{~N}$ & $P$ & $\mathrm{~N}$ & $P$ & $\mathrm{~N}$ & $P$ \\
\hline CLIA & - & 56 & - & 56 & 58 & 4 & - & 62 \\
\hline ECLIA & - & 82 & - & 82 & 85 & 5 & 1 & 89 \\
\hline EIA & - & - & - & - & - & - & - & - \\
\hline FEIA & - & 17 & - & 17 & 15 & 1 & 1 & 15 \\
\hline ICA & - & 1 & - & 1 & 1 & - & - & 1 \\
\hline MEIA & - & - & - & - & - & - & - & - \\
\hline Others & - & 1 & - & 1 & - & - & - & - \\
\hline Total & - & 157 & - & 157 & 159 & 10 & 2 & 167 \\
\hline
\end{tabular}

Abbreviations: Anti-HAV, anti-hepatitis A virus antibody; N, negative; P, positive; CLIA, chemiluminescence immunoassay; ECLIA, electro-chemiluminescence immunoassay; EIA, enzyme immunoassay; FEIA, fluorescence enzyme immunoassay; ICA, immunochromatography assay; MEIA, microparticle enzyme immunoassay.

하여 3개 이상의 제조회사 장비 및 시약으로 측정 후 발송하였 다.

간염바이러스 항원항체검사에 대한 검사방법은 2011년부 터 RPHA, PHA법 및 RIA법의 전통적인 방법의 시약이 단종 됨에 따라 CLIA 및 ECLIA법으로 전환되어 2016년 77.0\%$100.0 \%$ 의 기관에서, 2017 년 $74.7 \%-99.4 \%$ 의 기관에서 사용 하고 있었다. 이는 2015년도 $65 \%-69 \%$ 의 기관에서 사용하던 것과 비교하여 상당히 증가된 양상으로서 검사실의 자동화 장 비의 사용이 증가하였기 때문으로 생각된다[8]. 또한 간이검 
Journal of LABORATORY MEDICINE and QUALITY ASSURANCE

Eun-Jung Cho et al • Report on EQA for Hepatitis Viral Markers

Table 22. Results of 2016 anti-HAV immunoglobulin G proficiency testing

\begin{tabular}{|c|c|c|c|c|c|c|c|c|c|c|}
\hline \multirow{3}{*}{ Method } & \multicolumn{4}{|c|}{ 1st trial } & \multicolumn{6}{|c|}{ 2nd trial } \\
\hline & \multicolumn{2}{|c|}{ IL-16-01 } & \multicolumn{2}{|c|}{ IL-16-02 } & \multicolumn{2}{|c|}{ IL-16-03 } & \multicolumn{2}{|c|}{ IL-16-04 } & \multicolumn{2}{|c|}{ IL-16-05 } \\
\hline & $\mathrm{N}$ & $P$ & $\mathrm{~N}$ & $P$ & $\mathrm{~N}$ & $P$ & $\mathrm{~N}$ & $P$ & $\mathrm{~N}$ & $P$ \\
\hline CLIA & - & 112 & 1 & 111 & 111 & 3 & - & 114 & - & 114 \\
\hline ECLIA & - & 17 & - & 17 & 15 & 1 & - & 16 & - & 16 \\
\hline EIA & - & - & - & - & - & - & - & - & - & - \\
\hline FEIA & - & 1 & - & 1 & - & 1 & - & 1 & - & 1 \\
\hline ICA & - & 3 & - & 3 & 4 & - & 1 & 3 & 2 & 2 \\
\hline MEIA & - & - & - & - & - & - & - & - & - & - \\
\hline Others & - & - & - & - & - & - & - & - & - & - \\
\hline Total & - & 133 & 1 & 132 & 130 & 5 & 1 & 134 & 2 & 133 \\
\hline
\end{tabular}

Abbreviations: Anti-HAV, anti-hepatitis A virus antibody; N, negative; P, positive; CLIA, chemiluminescence immunoassay; ECLIA, electrochemiluminescence immunoassay; EIA, enzyme immunoassay; FEIA, fluorescence enzyme immunoassay; ICA, immunochromatography assay; MEIA, microparticle enzyme immunoassay.

Table 23. Results of 2017 anti-HAV immunoglobulin G proficiency testing

\begin{tabular}{|c|c|c|c|c|c|c|c|c|}
\hline \multirow{3}{*}{ Method } & \multicolumn{4}{|c|}{ 1st trial } & \multicolumn{4}{|c|}{ 2nd trial } \\
\hline & \multicolumn{2}{|c|}{ IL-17-03 } & \multicolumn{2}{|c|}{ IL-17-04 } & \multicolumn{2}{|c|}{ IL-17-07 } & \multicolumn{2}{|c|}{ IL-17-08 } \\
\hline & $\mathrm{N}$ & $P$ & $\mathrm{~N}$ & $P$ & $\mathrm{~N}$ & $P$ & $\mathrm{~N}$ & $P$ \\
\hline CLIA & - & 116 & - & 116 & 121 & 1 & - & 122 \\
\hline ECLIA & - & 16 & - & 16 & 20 & - & - & 20 \\
\hline EIA & - & - & - & - & - & - & - & - \\
\hline FEIA & - & 1 & - & 1 & 1 & - & - & 1 \\
\hline ICA & 1 & 2 & 1 & 2 & 5 & - & 1 & 4 \\
\hline MEIA & - & - & - & - & - & - & - & - \\
\hline Others & - & - & - & - & 1 & - & - & 1 \\
\hline Total & 1 & 135 & 1 & 135 & 148 & 1 & 1 & 148 \\
\hline
\end{tabular}

Abbreviations: Anti-HAV, anti-hepatitis A virus antibody; N, negative; P, positive; CLIA, chemiluminescence immunoassay; ECLIA, electro-chemiluminescence immunoassay; EIA, enzyme immunoassay; FEIA, fluorescence enzyme immunoassay; ICA, immunochromatography assay; MEIA, microparticle enzyme immunoassay.

사법인 ICA법을 장비를 사용하지 않는 기관을 포함하여 2016 년 0.9\%-23.0\%의 기관, 2017 년 0.6\%-25.3\%의 기관에서 사 용하고 있었다. 이는 2015년도에 $27 \%-34 \%$ 의 기관에서 ICA 법을 사용하였던 결과와 비교하면, ICA 사용기관의 분포가 감 소된 양상을 보이는 것으로, 2016년부터 검사실의 자동화 장 비의 사용이 증가하였기 때문으로 생각된다. 10 개의 종목 중 에서 2016년도에는 anti-HBc검사에서 CLIA 및 ECLIA법을 사용하는 기관의 비율이 가장 높았으며, 반면에 anti-HCV검 사에서 ICA법을 사용하는 기관의 비율이 가장 높았다. 2017년
도에는 anti-HAV검사에서 CLIA 및 ECLIA법을 사용하는 기 관의 비율이 가장 높았으며, 반면에 anti-HCV검사에서 ICA 법을 사용하는 기관의 비율이 2016년도와 동일하게 가장 높았 다.

$\mathrm{HBsAg}$ 과 anti-HBs검사에서 2016년 신빙도조사 결과, 양 성 검체의 일치율은 $95.8 \%-99.1 \%$ 로, 음성 검체의 일치율은 98.2\%-99.2\%로 매우 우수하였다. 2017년 신빙도조사 결과, $\mathrm{HBsAg}$ 과 anti- $\mathrm{HBs}$ 검사에서 양성 검체의 일치율은 $99.2 \%-$ $99.7 \%$ 로, 음성 검체의 일치율은 $99.5 \%-99.9 \%$ 로 매우 우수 하였다. Anti-HBc total 및 IgM검사에서 2016년 양성 및 음 성 검체의 일치율은 98.4\%-100.0\%, 2017년 양성 및 음성 검체의 일치율은 $99.2 \%-100.0 \%$ 로 높은 일치율을 보였다. $\mathrm{HBeAg}$ 검사에서 2016년 양성 검체의 일치율은 $94.0 \%$, 음 성 검체의 일치율은 $88.4 \%-100.0 \%, 2017$ 년 양성 검체의 일 치율은 $94.5 \%$, 음성 검체의 일치율은 $99.2 \%-100.0 \%$ 로 관찰 되었다. 2016년 신빙도조사사업에는 $\mathrm{HBeAg}$ 검사에 대한 양 성 검체(IL-16-04) 한 개가, 2017년도에도 양성 검체(IL-1705) 한 개가 포함되었다. 2016년도 ICA법을 사용하는 전체 15 개 기관 중에서 14 개(93.3\%)의 기관에서 이를 음성으로 보고, 2017년도 전체 15 개 기관 중에서 14 개(93.3\%)의 기관에서 음 성으로 보고하였다. 2016년과 2017년도 동일하게 ICA법을 사 용하는 $93.3 \%$ 의 기관에서 위음성으로 보고하여 일치율이 낮 아졌으며, $\mathrm{HBeAg}$ 검사의 ICA법에서 높은 위음성률을 보이 고 있었다. 또한 2016년 1차의 음성 검체(IL-16-02)에 대하여 CLIA 법을 사용하는 전체 138 기관 중 26 개(18.8\%)의 기관에 서, ICA법을 사용하는 전체 18 개의 기관 중에서 3 개(16.7\%) 의 기관에서만 양성으로 보고하여 전체 일치율이 $88.4 \%$ 로 낮 
Journal of LABORATORY MEDICINE and QUALITY ASSURANCE

Eun-Jung Cho et al • Report on EQA for Hepatitis Viral Markers

Table 24. Results of 2016 anti-HAV IgM proficiency testing

\begin{tabular}{|c|c|c|c|c|c|c|c|c|c|c|}
\hline \multirow{3}{*}{ Method } & \multicolumn{4}{|c|}{ 1st trial } & \multicolumn{6}{|c|}{ 2nd trial } \\
\hline & \multicolumn{2}{|c|}{ IL-16-01 } & \multicolumn{2}{|c|}{ IL-16-02 } & \multicolumn{2}{|c|}{ IL-16-03 } & \multicolumn{2}{|c|}{ IL-16-04 } & \multicolumn{2}{|c|}{ IL-16-05 } \\
\hline & $\mathrm{N}$ & $P$ & $\mathrm{~N}$ & $P$ & $\mathrm{~N}$ & $P$ & $\mathrm{~N}$ & $P$ & $\mathrm{~N}$ & $P$ \\
\hline CLIA & 135 & - & 135 & - & 136 & - & 136 & - & 136 & - \\
\hline ECLIA & 70 & 1 & 68 & 3 & 73 & 1 & 73 & 1 & 73 & 1 \\
\hline EIA & - & - & - & - & - & - & - & - & - & - \\
\hline FEIA & 22 & - & 22 & - & 22 & - & 22 & - & 22 & - \\
\hline ICA & 6 & - & 6 & - & 6 & - & 6 & - & 6 & - \\
\hline MEIA & - & - & - & - & - & - & - & - & - & - \\
\hline Others & 1 & - & 1 & - & 1 & - & 1 & - & 1 & - \\
\hline Total & 234 & 1 & 232 & 3 & 238 & 1 & 238 & 1 & 238 & 1 \\
\hline
\end{tabular}

Abbreviations: Anti-HAV, anti-hepatitis A virus antibody; N, negative; P, positive; CLIA, chemiluminescence immunoassay; ECLIA, electrochemiluminescence immunoassay; EIA, enzyme immunoassay; FEIA, fluorescence enzyme immunoassay; ICA, immunochromatography assay; MEIA, microparticle enzyme immunoassay.

Table 25. Results of 2017 anti-HAV IgM proficiency testing

\begin{tabular}{|c|c|c|c|c|c|c|c|c|}
\hline \multirow{3}{*}{ Method } & \multicolumn{4}{|c|}{ 1st trial } & \multicolumn{4}{|c|}{ 2nd trial } \\
\hline & \multicolumn{2}{|c|}{ IL-17-03 } & \multicolumn{2}{|c|}{ IL-17-04 } & \multicolumn{2}{|c|}{ IL-17-07 } & \multicolumn{2}{|c|}{ IL-17-08 } \\
\hline & $\mathrm{N}$ & $\mathrm{P}$ & $\mathrm{N}$ & $\mathrm{P}$ & $\mathrm{N}$ & $\mathbf{P}$ & $\mathrm{N}$ & $P$ \\
\hline CLIA & 14 & 121 & 134 & 1 & 145 & - & 145 & - \\
\hline ECLIA & 2 & 67 & 67 & 2 & 71 & - & 71 & - \\
\hline EIA & - & - & - & - & - & - & - & - \\
\hline FEIA & - & 21 & 21 & - & 20 & - & 20 & - \\
\hline ICA & 3 & 3 & 6 & - & 5 & - & 5 & - \\
\hline MEIA & - & - & - & - & - & - & - & - \\
\hline Others & - & 1 & 1 & - & - & - & - & - \\
\hline Total & 19 & 213 & 229 & 3 & 241 & - & 241 & - \\
\hline
\end{tabular}

Abbreviations: Anti-HAV, anti-hepatitis A virus antibody; N, negative; $\mathrm{P}$, positive; CLIA, chemiluminescence immunoassay; ECLIA, electro-chemiluminescence immunoassay; EIA, enzyme immunoassay; FEIA, fluorescence enzyme immunoassay; ICA, immunochromatography assay; MEIA, microparticle enzyme immunoassay.

게 관찰되었다. 2014년도 신빙도조사 결과에서도 간이검사법 인 ICA법을 사용하는 경우 음성 검체에서 위양성으로 보고하 는 경우도 있으나 대부분의 경우 양성 검체에서 위음성의 결과 를 보인다고 보고하였으며[7], $\mathrm{HBsAg}$ 신속검사법에 대한 메 타분석결과에서도 CLIA, EIA 및 MEIA법과 비교하여 ICA법 의 검출한계가 낮다고 보고한 바 있다[9]. 따라서 ICA법의 위 음성의 결과는 ICA법의 민감도가 낮기 때문인 것으로 판단되 므로 제품의 품질향상과 및 세심한 정도관리가 필요할 것으로 생각된다. 그러나 $\mathrm{HBeAg}$ 항목의 신빙도조사 결과 ICA법뿐만
아니라 CLIA 법을 사용하는 기관에서도 높은 위양성률을 보였 다. 이는 $\mathrm{HBeAg}$ 음성 검체의 제조과정에서 사용한 혼합혈청 의 matrix effect 때문이라 판단된다. 대규모의 신빙도조사 사 업용 검체는 한 개의 개별혈청을 사용하여 제조하는 것이 불 가능하므로 여러 명의 혈청을 혼합하여 만든 혼합혈청을 사용 한다. 혼합혈청의 경우 정도관리물질과 비교하여 교환가능성 (commutability)있는 장점이 있으나, 검체 제조과정에서 온도 및 시간에 따라서 검체의 matrix가 변하거나 혈청 내 존재하 는 다양한 단백질이 간섭물질로 작용하여 항원항체반응을 억 제할 수 있는 제한점이 있다고 알려져 있다[10]. $\mathrm{HBeAg}$ 검체 제조에 사용된 여러 환자의 검체 내에 존재하던 anti-HBs에 의한 matrix effect가 위양성을 유발할 가능성이 있으므로, 향 후 혼합혈청 제조 시 혼합하는 검체 수를 줄이고 다른 항원 및 항체검사를 통하여 일치되는 혈액을 혼합하여 matrix effect 를 최소화하는 노력이 필요할 것으로 생각되었다. 2017년도 검체 제조과정의 개선으로 2016 년도 $\mathrm{HBeAg}$ 음성 검체의 제 조과정에서 사용한 혼합혈청의 matrix effect로 인하여 발생 하였던 음성 검체의 위양성률은 2016 년도와 비교하여 높은 일 치율을 보였다. Anti-HBe검사에서 2016년 양성 검체의 일치 율은 97.4\%-98.7\%, 음성 검체의 일치율은 98.2\%-100.0\%, 2017년 양성 검체의 일치율은 $97.4 \%$, 음성 검체의 일치율은 98.3\% - 100.0\%로 양성 검체의 일치율보다 다소 높았다. 이는 양성 검체에 대하여 ICA법을 사용하는 2 개의 기관에서 모두 음성으로 보고한 위음성 결과 때문으로 생각된다.

Anti-HCV검사에서 2016년 양성 검체의 일치율은 98.7\%$99.9 \%$ 로, 음성 검체의 일치율은 $81.1 \%-99.6 \%$ 로 일부 음성 검체에서의 일치율이 낮았다. 2017년 양성 검체의 일치율은 


\section{Journal of LABORATORY MEDICINE and QUALITY ASSURANCE}

\section{Eun-Jung Cho et al • Report on EQA for Hepatitis Viral Markers}

99.7\%-99.9\%로, 음성 검체의 일치율은 99.9\%-100.0\%로 매 우 우수하였다. 2016년도 양성 검체의 일치율은 2015년 신빙 도조사 결과 99.5\%-99.8\%과 유사한 일치율을 보였으나, 음 성 검체의 일치율은 $99.6 \%-99.8 \%$ 와 비교하여 낮게 관찰되었 다. 그러나 2017년 음성 검체의 일치율은 2016년도와 비교하 여 높은 일치율을 보였다. ICA법을 사용하는 기관이 2015년 도에는 $34.0 \%$ 였던 반면, 2016 년에는 $23.0 \%$ 로 감소하였다가, 2017 년에는 $25.3 \%$ 로 약간 증가한 양상을 보여 다른 검사항 목에 비하여 여전히 ICA법을 많이 사용하고 있었다. CLIA 및 ECLIA 법과 비교하여 낮은 검출 민감도를 보임에도 불구하고, 양성 검체에서 높은 일치율을 보여 국내 ICA검사키트의 성능 이 향상되었다고 판단된다. 2016년 1차의 음성 검체(IL-1602)에서 낮은 일치율을 보인 것은 ECLIA법을 사용하는 전체 174 기관 중에서 123 개(70.7\%)의 기관에서 위양성으로 보고 하였기 때문이다. 이는 $\mathrm{HBeAg}$ 음성 검체와 마찬가지로 anti$\mathrm{HCV}$ 가 음성인 여러 환자의 혈청을 혼합하여 검체가 제조되 었으므로, matrix effect로 인하여 특정 장비 및 시약에서 양성 결과를 보인 것이라 판단되었다. 그러나 2017년도 검체 제조 과정의 개선으로 2016 년도와 비교하여 음성 검체 일치율이 향 상되었다.

Anti-HAV total검사에서 2016년 양성 검체의 일치율은 98.7\%-98.0\%, 음성 검체의 일치율은 $92.1 \%$ 로 양성 검체의 일치율보다 낮았다. IL-06-03 검체의 anti-HAV total검사에 서는 FEIA법, CLIA법, ECLIA법 순으로 높은 위양성률을 보 였으며, 각각 $30.8 \%, 5.8 \%, 5.4 \%$ 의 기관에서 위양성으로 보 고하였다. 2017년 양성 검체의 일치율은 98.8\%-100.0\%, 음 성 검체의 일치율은 $94.1 \%$ 로 양성 검체의 일치율보다 낮았 다. IL-07-07 검체의 anti-HAV total검사에서는 CLIA 법, FEIA법, ECLIA법 순으로 높은 위양성률을 보였으며, 각각 $6.5 \%, 6.7 \%, 5.9 \%$ 의 기관에서 위양성으로 보고하였다. Anti$\mathrm{HAV}$ IgG검사에서 2016년 양성 검체의 일치율은 98.5\%$100.0 \%$, 음성 검체의 일치율은 $96.3 \%$ 로 매우 우수하였다. 그 러나 ICA법을 사용하는 경우 2016년 2차 신빙도조사에서 2개 의 양성 검체에 대하여 각각 $25 \%, 50 \%$ 의 기관이 위음성으로 보고하였다. 또한 위양성으로 보고한 경우 FEIA법, ECLIA 법, CLIA 법 순으로 높은 위양성률을 보였으며, 각각 $100.0 \%$, $6.3 \%, 2.6 \%$ 의 기관에서 위양성으로 보고하였다. 2017 년 양성 검체의 일치율은 $99.3 \%$, 음성 검체의 일치율은 $99.3 \%$ 로 매 우 우수하였다. 그러나 ICA법을 사용하는 경우 2017년 1차 신 빙도조사에서 2개의 양성 검체(IL-07-03, IL-07-04)에 대하여 $50 \%$ 의 기관이, 2 차에서 한 개의 양성 검체(IL-07-08)에 대하 여 20\%의 기관이 위음성으로 보고하였다. 2016년 anti-HAV
$\operatorname{IgM}$ 검사 대한 신빙도조사는 모두 음성 검체가 사용되었으며, 일치율은 98.3\%-99.6\%로 매우 높게 관찰되었다. 위양성으로 보고한 경우는 모두 ECLIA 법을 사용하는 $1.4 \%-4.2 \%$ 의 기 관이었다. 2017년 신빙도조사는 양성 검체(IL-17-03) 한 개가 포함되었으며, 양성 검체의 일치율은 $91.8 \%$, 음성 검체의 일 치율은 98.7\%-100.0\%로 양성 검체의 일치율이 낮게 관찰되 었다. 위음성으로 보고한 경우는 CLIA법 14 개 기관(10.4\%), ECLIA 법 2개 기관(2.9\%), ICA법 3 개의 기관 $(50.0 \%)$ 이었 다. 2016년도 음성 검체의 일치율과 비교하여 2017년도 anti$\mathrm{HAV} \mathrm{IgM}$ 검사에서 음성 검체의 일치율이 더 향상되었다. 그 러나 2017년도 신빙도조사에서 처음으로 anti-HAV IgM검사 에서 양성 검체를 사용한 결과 위양성 보고로 인한 낮은 일치 율을 보였다. Anti-HAV검사는 간염바이러스 항원항체검사 중에서 자동화 장비를 사용하는 비율이 상대적으로 가장 높은 항목이며, 특히 anti-HAV total과 IgM검사를 동시에 시행하 는 기관 수가 많으므로 anti-HAV 자동화 검사법의 민감도 향 상이 필요할 것으로 생각된다. 또한 anti-HAV $\operatorname{IgM}$ 및 $\operatorname{IgG}$ 검 사의 ICA법을 사용하는 기관에서 위음성 결과가 많이 발생하 였으므로 ICA검사키트의 품질개선 및 검사실에서의 보다 엄 격한 질 관리가 요구된다.

결론적으로, 2016년 및 2017년도 간염바이러스 항원항체검 사의 신빙도조사사업은 10 가지 종목에 대하여 시행하였으며, 본 연구의 통계분석자료가 참여기관에서 신빙도조사 결과를 해석하고 검사법 선택 시 유용할 것으로 생각된다. 또한 지속 적인 신빙도조사사업 참여를 통하여 간염바이러스 항원항체 검사의 질 향상이 필요하다.

\section{감사의 글}

이 논문은 대한임상검사정도관리협회 2016년 및 2017년 학 술연구비 지원에 의해 이루어진 것이다.

\section{REFERENCES}

1. Kang DY, Kim KH, Lee DH, Lee YW, Park CK. Report on serology survey in Korea 1982. J Lab Med Qual Assur 1983;5:39-44.

2. Cho HI, Kang DY, Kim SI, Kim KH, Lee YW, Choi S, et al. Annual report on quality assessment in immunoserology and blood bank tests in Korea (1983). J Lab Med Qual Assur 1984;6:31-8.

3. Chi HS, Kang DY, Kim HS, Park MH, Shim JW, Lee DH, 


\section{Journal of LABORATORY MEDICINE and QUALITY ASSURANCE}

Eun-Jung Cho et al • Report on EQA for Hepatitis Viral Markers

et al. Annual report on external quality assessment in immunoserology in Korea (1986). J Lab Med Qual Assur 1987;9:37-46.

4. Kim HS, Kim DW, Kim JS, Kim TY, Park MH, Park AJ, et al. Annual report on external quality assessment in immunoserology in Korea (1993). J Lab Med Qual Assur 1994;16:33-46.

5. Cha YJ, Kwon SY, Kum DG, Kim SW, Kim TY, Kim JR, et al. Annual report on external quality assessment in immunoserology in Korea (2004). J Lab Med Qual Assur 2005;27:37-57.

6. Lee JH, Cha YJ, Bae JH, Chae SL; Immunoserology Subcommittee, The Korean Association of Quality Assurance for Clinical Laboratory. Annual report on external quality assessment of viral markers and serological tests for syphilis in Korea (2013). J Lab Med Qual Assur 2014;36:16170.

7. Cha YJ, Bae JH, Park Q, Chae SL; Immunoserology Sub- committee, The Korean Association of External Quality Assessment Service. Annual report on the external quality assessment scheme of viral markers and serological tests for syphilis in Korea (2014). J Lab Med Qual Assur 2015;37:124-33.

8. Cha YJ, Bae JH, Jung YS, Chae SL; Immunoserology Subcommittee, Korean Association of External Quality Assessment Service. Annual report on the external quality assessment scheme of viral markers and serological tests for syphilis in Korea (2015). J Lab Med Qual Assur 2016;38:214-24.

9. Hwang SH, Oh HB, Choi SE, Kim HH, Chang CL, Lee EY, et al. Meta-analysis for the pooled sensitivity and specificity of hepatitis B surface antigen rapid tests. Korean J Lab Med 2008;28:160-8.

10. Miller WG. Specimen materials, target values and commutability for external quality assessment (proficiency testing) schemes. Clin Chim Acta 2003;327:25-37. 
${ }^{1}$ 가톨릭대학교 의과대학 의정부성모병원 진단검사의학과, ${ }^{2}$ 가톨릭대학교 의과대학 서울성모병원 진단검사의 학과, ${ }^{3}$ 가톨릭대학교 대학원 의생명건강과학과 분자세포생물학, ${ }^{4}$ 울산대학교 의과대학 서울아산병원 진단검사 의학과

대한임상검사정도관리협회 면역혈청프로그램의 2016년 간염바이러스 항원항체검사 신빙도조사 사업은 6 월과 10 월에, 2017년 신빙도조사사업은 5월과 10월에 2회에 걸쳐 시행되었다. 간염바이 러스 항원항체검사 신빙도조사사업은 총 10종목에 대하여 실시하였다. 저자들은 2016년 1회차 2

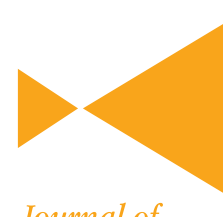

Journal of

LABORATORY MEDICINE

and

QUALITY ASSURANCE 개, 2회차 3개의 혼합혈청 검체를 각각 965 기관, 962 기관에 발송하였다. 참여기관은 1회차에 915 기관(94.8\%), 2회차 913기관(95.0\%)이었다. 2017년도에는 매 회차 3개의 혼주혈청 검체를 각각 936기관, 1,015 기관에 발송하였다. 참여기관은 1회차에 920기관(98.3\%), 2회차 996기관(98.1\%) 이었다. Hepatitis B surface antigen에 가장 많은 기관이 참여하였고, hepatitis B surface antigen, anti-hepatitis C virus, hepatitis B envelope antigen, antibodies to hepatitis B envelope antigen, antihepatitis A virus 및 antibodies to hepatitis B core antigen 순으로 참여하였다. 간염바이러스 항원항 체검사 신빙도조사 결과, matrix effect로 인하여 전기화학발광면역검사법을 포함한 화학발광면역검 사법에서 위양성 결과가 발생하였다. Anti-hepatitis A virus검사에서 면역크로마토그래피법의 낮은 민감도는 위음성 결과를 초래하였다. 검사실의 간염바이러스 신빙도조사사업의 지속적인 참여를 통한 검사의 질 향상이 필요할 것으로 생각되었다.

(J Lab Med Qual Assur 2018;40:51-69)

교신저자: 오은지

우)06591 서울시 서초구 반포대로 222, 가톨릭대학교 의과대학 서울성모병원 진단검사의학과

Tel: 02)2258-1641, Fax: 02)2258-1719, E-mail: ejoh@catholic.ac.kr 